\title{
Gene expression signature of atypical breast hyperplasia and regulation by SFRP1
}

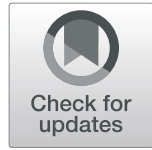

Kelly J. Gregory ${ }^{1}$, Amy L. Roberts², Erin M. Conlon³, Jacob A. Mayfield ${ }^{9}$, Mary J. Hagen², Giovanna M. Crisi ${ }^{4}$,

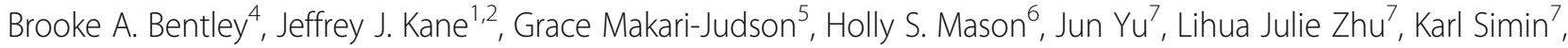
Jacob P. S. Johnson ${ }^{7}$, Ashraf Khan ${ }^{8}$, Ben R. Schneider ${ }^{1}$, Sallie S. Schneider ${ }^{1,2^{*}+}$ and D. Joseph Jerry ${ }^{1,2^{*}+}$ (D)

\begin{abstract}
Background: Atypical breast hyperplasias (AH) have a 10-year risk of progression to invasive cancer estimated at 4-7\%, with the overall risk of developing breast cancer increased by $\sim 4$-fold. AH lesions are estrogen receptor alpha positive (ERa+) and represent risk indicators and/or precursor lesions to low grade ERa+tumors. Therefore, molecular profiles of $\mathrm{AH}$ lesions offer insights into the earliest changes in the breast epithelium, rendering it susceptible to oncogenic transformation.
\end{abstract}

Methods: In this study, women were selected who were diagnosed with ductal or lobular AH, but no breast cancer prior to or within the 2-year follow-up. Paired AH and histologically normal benign (HNB) tissues from patients were microdissected. RNA was isolated, amplified linearly, labeled, and hybridized to whole transcriptome microarrays to determine gene expression profiles. Genes that were differentially expressed between AH and HNB were identified using a paired analysis. Gene expression signatures distinguishing AH and HNB were defined using AGNES and PAM methods. Regulation of gene networks was investigated using breast epithelial cell lines, explant cultures of normal breast tissue and mouse tissues.

Results: A 99-gene signature discriminated the histologically normal and AH tissues in 81\% of the cases. Network analysis identified coordinated alterations in signaling through ERa, epidermal growth factor receptors, and androgen receptor which were associated with the development of both lobular and ductal AH. Decreased expression of SFRP1 was also consistently lower in AH. Knockdown of SFRP1 in 76N-Tert cells resulted altered expression of 13 genes similarly to that observed in AH. An SFRP1-regulated network was also observed in tissues from mice lacking Sfrp1. Re-expression of SFRP1 in MCF7 cells provided further support for the SFRP1-regulated network. Treatment of breast explant cultures with rSFRP1 dampened estrogen-induced progesterone receptor levels.

Conclusions: The alterations in gene expression were observed in both ductal and lobular AH suggesting shared underlying mechanisms predisposing to AH. Loss of SFRP1 expression is a significant regulator of AH transcriptional profiles driving previously unidentified changes affecting responses to estrogen and possibly other pathways. The gene signature and pathways provide insights into alterations contributing to $\mathrm{AH}$ breast lesions.

Keywords: Atypical hyperplasia, Breast, Lobular, Ductal, Premalignancy, SFRP1, Gene expression profile

\footnotetext{
* Correspondence: Sallie.Schneider@baystatehealth.org;

jjerry@vasci.umass.edu

'Sallie S. Schneider and D. Joseph Jerry contributed equally to this work.

'Pioneer Valley Life Sciences Institute, Springfield, MA 01199, USA

Full list of author information is available at the end of the article
}

(C) The Author(s). 2019 Open Access This article is distributed under the terms of the Creative Commons Attribution 4.0 International License (http://creativecommons.org/licenses/by/4.0/), which permits unrestricted use, distribution, and

reproduction in any medium, provided you give appropriate credit to the original author(s) and the source, provide a link to the Creative Commons license, and indicate if changes were made. The Creative Commons Public Domain Dedication waiver (http://creativecommons.org/publicdomain/zero/1.0/) applies to the data made available in this article, unless otherwise stated. 


\section{Background}

Studies of premalignant breast lesions provide insights into the mechanisms rendering the breast epithelium susceptible to oncogenic transformation as well as identify interventions that could prevent breast cancer. Atypical hyperplasias $(\mathrm{AH})$ develop in the terminal duct lobular units of the breast and are further subdivided into either atypical ductal hyperplasia $(\mathrm{ADH})$ or lobular neoplasia (LN). Lobular neoplasia encompasses atypical lobular hyperplasia (ALH) and lobular carcinoma in situ (LCIS). In addition, flat epithelia atypia (FEA) is a subtype of atypical ductal epithelium lacking architectural changes as seen in $\mathrm{ADH}$. The 10-year risk of progression to invasive cancer is estimated to be $7 \%$ for all $\mathrm{AH}$ [1] with a cumulative incidence approaching $35 \%$ at 30 years. The overall risk of developing breast cancer is increased by $\sim 4$-fold among women with atypia and is similar for both ductal and lobular lesions $[1,2]$. However, the risk is most prominent among women with higher breast density [3] suggesting that mechanisms underlying breast density affect the progression of premalignant breast lesions. $\mathrm{AH}$ lesions are most often positive for estrogen receptor alpha $(E R \alpha+)$ and approximately 90\% of tumors that develop subsequently are ER $\alpha$-positive. Thus, AH represent a precursor lesion to low-grade ER $\alpha$-positive tumors. Selective receptor modulators or aromatase inhibitors prevent progression of $\mathrm{AH}$ to invasive carcinomas by about $60 \%$ [4-6], further supporting an important role for estrogen signaling in malignant progression of $\mathrm{AH}$.

The expression of several genes and proteins have been evaluated in $\mathrm{AH}$ and their relationship with risk of progression. CK5/6 and ER $\alpha$ can aid the morphologic interpretation of usual ductal hyperplasia and $\mathrm{AH}$ lesions and increase the sensitivity of distinguishing among these lesions $[7,8]$. However, levels of ER $\alpha$ in $\mathrm{AH}$ detected by immunohistochemical staining did not predict risk of breast cancer [9]. The extent of Ki67 immunoreactivity in normal breast tissue has been associated with an increased risk of breast cancer [10]. Combined measures of proliferation, tumor suppressor activity, and inflammatory signaling within $\mathrm{AH}$, using immunohistochemical scoring for Ki67, p16, and COX-2 respectively, have been used to evaluate breast cancer risk [11]. Elevated levels of EZH2 were shown to be an early marker for progression of preneoplastic lesions [12], while other studies identified increases in DNA methylation within promoter elements of tumor suppressor genes such as APC, DLEC1, HOXA1, RASSF1A, and SFRP1 [13, 14]. Progressive methylation of genes in early lesions was reported for RASSF1A and $R A R B 2$, suggesting the potential value of these targets [15]. Higher levels of estrogen receptor beta (ER $\beta)$ are associated with a decreased risk of progression of $\mathrm{AH}$ [16], suggesting that selective agonists of ER $\beta$ may offer potential therapy for chemoprevention. Gene expression profiles have also been used to identify early changes in $\mathrm{AH}$ as well as adjacent tumors [17, 18]. These studies suggest the presence of molecular changes within breast epithelial cells associated with the transition to $\mathrm{AH}$ and risk of progression to breast cancer.

In the present study, patients diagnosed with $\mathrm{AH}$ and no history of breast cancer (prior to or within the 2-year follow-up after AH diagnosis) were selected. Laser capture microdissection was used to collect both histologically normal benign epithelium (HNB) and $\mathrm{AH}$ tissues from each patient. The complete transcriptome was evaluated by microarray, and gene expression patterns were used to define signatures that distinguish $\mathrm{AH}$ lesions from HNB tissues. Although ADH and LN tissues have distinct morphologic features, they did not form distinct clusters based on gene expression patterns suggesting that these premalignant lesions share underlying alterations in transcriptional programs. Pathway analyses identified genes encoding $E R \alpha$, epidermal growth factor receptors (ERB-B), and androgen receptor (AR) as central nodes in the expression profiles. ERB-B2 and WNT signaling pathways were also strongly overrepresented among the genes differentially expressed in AH. As methylation and loss of SFRP1 expression had been associated with premalignancy, we determined if it may be responsible for altered expression of a subset of genes altered in AH. Knock down of SFRP1 expression in normal breast epithelial cells (76N-Tert) identified 13 genes within the $\mathrm{AH}$ signature that had not previously been connected to SFRP1. SFRP1-regulated genes were also observed in mammary tissue from mice bearing deletion of the Sfrp1 gene. Re-expression of SFRP1 in an ER $\alpha$-positive breast cancer cell line (MCF7), which has lost expression of the endogenous SFRP1 gene, had the opposite effect providing additional confirmation of an SFRP1-regulated gene network. Antagonism of estrogeninduced responses in progesterone receptor levels was demonstrated by addition of recombinant SFRP1 to human breast explant cultures. These findings demonstrate that SFRP1 expression is diminished in AH resulting in deregulation of a larger program of genes and loss of restraint on ER $\alpha$ signaling which may contribute to development of premalignant breast lesions.

\section{Methods}

\section{Patient specimens}

This is a retrospective study using formalin-fixed and paraffin-embedded (FFPE) archival tissue blocks. A search of pathology electronic files (CoPath) included patients with isolated $\mathrm{AH}$ lesions (atypical ductal hyperplasia, flat epithelial atypia, atypical lobular hyperpalsai, classic type lobular carcinoma in-situ) on core biopsy with subsequent excisional biopsy, isolated $\mathrm{AH}$ lesions on primary excisional biopsies, and reduction mammoplasties. Exclusion 
criteria included patients with a prior history of breast cancer or breast cancer within 2 years of initial $\mathrm{AH}$ diagnosis or insufficient $\mathrm{AH}$ lesion on subsequent excision. Original diagnoses were supported by at least two pathologists. A subspecialized breast pathologist (GMC) reviewed all cases retrieved for the study for concordance of original diagnosis. Cases that, upon review by GMC, did not meet histopathologic criteria for $\mathrm{AH}$ (ductal or lobular) were excluded. Characteristics of patients and diagnoses are in Table 1. Patient 14 was found to have a diagnosis of severe ADH bordering on ductal carcinoma in situ (low grade) upon review of original slide material. Institutional Review Board approval was obtained from Baystate Health, Springfield, MA (protocol number 182463).

Table 1 Patient characteristics and array identifiers

\begin{tabular}{|c|c|c|c|c|c|}
\hline $\begin{array}{l}\text { Patient } \\
\text { ID }\end{array}$ & $\begin{array}{l}\text { Age at } \\
\text { diagnosis }\end{array}$ & Diagnosis & $\begin{array}{l}\text { Affected } \\
\text { breast }\end{array}$ & $\begin{array}{l}\text { Atypia } \\
\text { array ID }\end{array}$ & $\begin{array}{l}\text { Benign } \\
\text { array ID }\end{array}$ \\
\hline 1 & 43 & FEA & Left & JJ013 & JJ014 \\
\hline 2 & 46 & LCIS & Right & JJ001 & JJ002 \\
\hline 3 & 47 & $\mathrm{ADH}$ & Right & JJ005 & Jנ006 \\
\hline 4 & 58 & LCIS & Left & JJ015 & JJ016 \\
\hline 5 & 40 & $\mathrm{ADH}, \mathrm{FEA}$ & Right & JJ003 & JJ004 \\
\hline 6 & 63 & $\mathrm{ADH}$ & Left & Jנ007 & JJ008 \\
\hline 7 & 52 & LCIS & Right & Jנ009 & JJ010 \\
\hline 8 & 62 & $\mathrm{ADH}, \mathrm{FEA}$ & Left & JJ012 & JJ011 \\
\hline 9 & 46 & LCIS & Left & JJ017 & JJ018 \\
\hline 10 & 40 & $\mathrm{ADH}$ & Right & JJ019 & $N A^{@}$ \\
\hline 11 & 49 & $\begin{array}{l}\text { ADH, } \\
\text { ALH }\end{array}$ & Left & DJJ021 & DJJ022 \\
\hline 12 & 53 & $\mathrm{ALH}, \mathrm{FEA}$ & Right & DJJ023 & DJJ024 \\
\hline 13 & 53 & LCIS & Left & DJJ025 & DJJ026 \\
\hline $14^{*}$ & 58 & $\mathrm{ADH}$ & Right & DJJ027 & DJJ028 \\
\hline 15 & 60 & LCIS, ALH & Left & DJJ029 & DJJ030 \\
\hline $\begin{array}{l}\text { 16- } \\
\text { Block1** }\end{array}$ & 52 & $\mathrm{ADH}, \mathrm{FEA}$ & Right & DJJ031 & DJJ032 \\
\hline $\begin{array}{l}\text { 16- } \\
\text { Block2** }\end{array}$ & 52 & $\mathrm{ADH}, \mathrm{FEA}$ & Right & DJJ033 & $N A^{* * *}$ \\
\hline 18 & 47 & ALH & Left & DJJ035 & DJJ036 \\
\hline 19 & 55 & $\mathrm{ALH}$ & Right & DJJ037 & DJJ038 \\
\hline 20 & 70 & $\begin{array}{l}\mathrm{ADH} \\
\text { severe }\end{array}$ & Right & DJJ039 & DJJ040 \\
\hline 21 & 44 & FEA & Right & DJJ041 & DJJ042 \\
\hline 22 & 50 & $\mathrm{ADH} / \mathrm{FEA}$ & Left & DJJ043 & DJJ044 \\
\hline 23 & 54 & $\begin{array}{l}\text { ADH/ } \\
\text { DCIS }\end{array}$ & Left & DJJ045 & DJJ046 \\
\hline
\end{tabular}

*Confirming records revealed that patient 14 followed up with DCIS in left breast 6 months later

**For patient 16 , two independent blocks with $\mathrm{AH}$ were analyzed separately ***There was insufficient benign tissue for Patient 16-Block2

${ }^{\circledR}$ Defective array

\section{Microscopic evaluation}

Atypical hyperplasias (AH) arise in the terminal duct lobular units of the breast and are divided into ductal and lobular subtypes based on cytomorphologic characteristics. Ductal lesions included in the study are atypical ductal hyperplasia (ADH) and flat epithelial atypia (FEA); lobular lesions included atypical lobular hyperplasia (ALH) and/or classic lobular carcinoma in situ (LCIS), representing a spectrum and also known as lobular neoplasia. Subjects with either ductal or lobular atypia were included in the analysis to assess differences in transcriptional features. Areas of AH and benign ducts/lobules were marked for microdissection by the breast pathologist. RNA of sufficient quantity and quality was obtained from $21 \mathrm{AH}$ lesions (from 20 patients). The tissues included 8 lobular lesions (ALH and/or LCIS), 11 ductal lesions (ADH and/or FEA), and 2 that were a mixture of ductal and lobular lesions. All subjects were female; the mean age was 51.9 years $(\mathrm{SD}=7.9$ years).

\section{Analysis of RNA integrity}

The integrity of RNA in tissue sections was assessed by amplifying 5' fragment (nucleotides 1355-1472) and 3' fragment (nucleotides 1650-1717) of the $\beta$-actin gene (Additional file 2: Table S5) by quantitative RT-PCR (RTqPCR). An 8- $\mu \mathrm{m}$ section from each tissue block was placed on a glass microscope slide in RNase-free conditions, deparaffinized in 3 changes of xylene, and allowed to airdry under vacuum in a desiccator for $30 \mathrm{~min}$. The tissue sample was scraped from the slide using a razor blade directly into $150 \mu \mathrm{l}$ digestion buffer containing $10 \mu \mathrm{l}$ proteinase K (miRNeasy FFPE Kit, Qiagen, Germantown, MD) and incubated at $55^{\circ} \mathrm{C}$ for $2 \mathrm{~h}$. The samples were subsequently incubated at $80^{\circ} \mathrm{C}$ for $15 \mathrm{~min}$ and transferred to ice for $3 \mathrm{~min}$. The samples were centrifuged at $13,000 \times \mathrm{g}$ for $20 \mathrm{~min}$, and the supernatant was transferred to new tubes. The RNA was harvested following DNase digestion using the miRNAeasy FFPE kit as described in the manufacturer's instructions (Qiagen). The cDNA was prepared using 100 ng total RNA, oligo dT primers, and the Transcriptor first strand cDNA synthesis kit according to the manufacturer's instructions (Roche, Indianapolis, IN). Amplification of $5^{\prime}$ and 3' $\beta$-Actin targets were performed using the KAPA SYBR Fast Master Mix (Thermo Fisher, Waltham, MA) containing $200 \mathrm{nM}$ forward primer, $200 \mathrm{nM}$ reverse primer, and $5 \mu \mathrm{l} \mathrm{cDNA}$. The conditions for mRNA amplification were performed as follows: 40 cycles each of 1 cycle at $95^{\circ} \mathrm{C}$ for $2 \mathrm{~min}, 1 \mathrm{cycle}$ at $95^{\circ} \mathrm{C}$ for $15 \mathrm{~s}$, and 1 cycle at $60^{\circ} \mathrm{C}$ for $30 \mathrm{~s} ; 1$ cycle at $95^{\circ} \mathrm{C}$ for $15 \mathrm{~s}, 1$ cycle at $60^{\circ} \mathrm{C}$ for $15 \mathrm{~s}, 20 \mathrm{~min}$ ramp, and 1 cycle at $95^{\circ} \mathrm{C}$ for $15 \mathrm{~s}$. The $C_{\mathrm{t}}$ value of the 3' $\beta$-Actin target was subtracted from the $C_{\mathrm{t}}$ value of the $5^{\prime} \beta$-Actin target to determine the amplification ratio. Specimens with ratios $<5$ were used for microdissection and transcriptome-wide profiling. 


\section{Microdissection and RNA isolation}

The H\&E stained sections of the AH samples were used to estimate the total area for microdissection. A minimum area of $10 \times 10^{6} \mu \mathrm{m}^{2}$ was required to ensure a minimum of $50 \mathrm{ng}$ total RNA. Consecutive tissue sections $(8-\mu \mathrm{m}$ thick) were cut using RNase-free conditions and mounted on membrane slides (MMI, Rockledge, FL) . The first and every 4th section were H\&E stained for microscopic evaluation to confirm that $\mathrm{AH}$ tissue was present in unstained microdissected areas. The AH lesion and benign glandular tissue were marked by a breast pathologist (GMC) for microdissection. The benign glandular areas were selected to be at least $1 \mathrm{~cm}$ away from the $\mathrm{AH}$ lesion in the same tissue block or a different block. The tissues on membrane slides were deparaffinized in 3 changes of xylenes and allowed to air-dry under a vacuum in a desiccator for $30 \mathrm{~min}$ prior to laser capture microdissection. The unstained sections were oriented for microdissection aided by landmarks defined on the H\&E stained slides. Areas to be microdissected were circumscribed using MMI Cell Tools software (Version Celltools-4.4 \#261, Rockledge FL). Microdissected AH and HNB tissues from each patient were collected separately onto caps (MMI Inc., Rockledge FL). The microdissected tissue was collected in $150 \mu \mathrm{l}$ digestion buffer containing $10 \mu \mathrm{l}$ proteinase $\mathrm{K}$ (miRNeasey FFPE Kit, Qiagen), was kept overnight at $55^{\circ} \mathrm{C}$, and was stored at $-80^{\circ} \mathrm{C}$ until further processing. Total RNA was isolated from microdissected tissue using the miRNeasy FFPE Kit (Qiagen) according to the manufacturer's instructions and quantified using a NanoDrop ${ }^{\text {sx }} 1000$ (Thermo Fisher Scientific).

\section{cDNA synthesis, amplification, and labeling}

The Ovation FFPE WTA System (NuGEN, San Carlos, CA) was used to prepare amplified cDNA from FFPEderived total RNA because amplification is initiated at the 3 ' end as well as randomly throughout the whole transcriptome in the sample which makes this system ideal for amplification of RNA obtained from FFPE samples. Fifty nanograms of RNA was used to prepare the cDNA according to the manufacturer's instructions. The cDNA was then purified using columns from the QIAquick PCR Purification kit (Qiagen). Buffer PB from the purification kit was added to the cDNA reaction, loaded on to the column, and centrifuged for $1 \mathrm{~min}$ at $13,000 \times \mathrm{g}$. The flow through was discarded, and $80 \%$ ethanol was added to the column and centrifuged for $1 \mathrm{~min}$ at $13,000 \times \mathrm{g}$. The $80 \%$ ethanol wash step was repeated, and the purified cDNA was eluted with nuclease-free water. An aliquot containing $5 \mu \mathrm{g}$ of cDNA was fragmented and labeled using the Encore ${ }^{\circ}$ Biotin Module (NuGEN) according to the manufacturer's instructions. The biotin-labeled cDNA was hybridized to Affymetrix 1.0 ST microarrays by Genome Explorations (Memphis, TN).

\section{Analysis of microarray data}

The data were normalized using the Single-Channel Array Normalization (SCAN) and Universal exPression Codes (UPC) methods from the BioConductor $\mathrm{R}$ package "SCAN.UPC" [19]. This package produces standardized expression measures that are used to estimate whether a given gene or probe is active in a specific sample [20,21]. ComBAT, an empirical Bayesian framework, was used to adjust data for batch effects [22]. The normalized data are available from the NCBI Gene Expression Omnibus Repository [23] series record GSE118432. Limma [24] was used to identify differentially expressed genes in a pairedsample model, with $\mathrm{HNB}$ and $\mathrm{AH}$ samples paired by patient. AH arrays JJ019 and DJJ033 were excluded from the analysis because paired HNB data were not available for these patients. A total of 1039 probesets were selected with adjusted $p<0.05$. Two methods were employed to identify gene signatures distinguishing $\mathrm{AH}$ and normal benign tissue. Agglomerative clustering was performed using AGNES [25] to visualize gene expression patterns. Prediction Analysis of Microarrays (PAM) was used as an alternative approach to define a minimal gene expression signature [26].

\section{Network analysis}

The differentially expressed probesets were mapped to 812 unique genes and used for network analysis [27]. In cases where there were more than one probeset for a gene, the data were averaged. Protein interaction networks were constructed using the STRING database available within the network analyst tool (http://www.networkanalyst.ca/). Over-representation of KEGG pathways was determined, and pathways were visualized using Cytoscape [28].

\section{Analysis of genes dependent on SFRP1}

The 76N-Tert cell line was derived from normal breast epithelial cells [29] and expresses endogenous SFRP1. Generation and cultivation of engineered human cell lines (TERT-pSUPER, TERT-siSFRP1, MCF7-pCDNA, MCF7-SFRP1) has been described previously [30-32]. Total RNA was extracted from cell lines using an acidphenol extraction procedure [33], according to the manufacturer's instructions (Trizol, Invitrogen, Carlsbad, CA). Relative levels of mRNA were determined by using the 1-Step Brilliant ${ }^{\circ}$ SYBRIII $^{\circ}$ Green RT-qPCR Master Mix Kit (Stratagene) containing $200 \mathrm{nM}$ forward primer, $200 \mathrm{nM}$ reverse primer, and $100 \mathrm{ng}$ total RNA. The conditions for cDNA synthesis and target mRNA amplification were performed as follows: 1 cycle of $50^{\circ} \mathrm{C}$ for 30 min, 1 cycle of $95^{\circ} \mathrm{C}$ for $10 \mathrm{~min}$, and 35 cycles each of $95^{\circ} \mathrm{C}$ for $30 \mathrm{~s}, 55^{\circ} \mathrm{C}$ for $1 \mathrm{~min}$, and $72^{\circ} \mathrm{C}$ for $30 \mathrm{~s}$. Expression of each gene was normalized to levels of $\beta$-actin mRNA. The PCR primer sequences used are described in Additional file 2: Table S5. 


\section{Animals}

The study was carried out in strict accordance with the recommendations in the Guide for the Care and Use of Laboratory Animals of the National Institutes of Health. The protocol was approved by the Baystate Medical Center Institutional Animal Care and Use Committee (Permit Number: 132681). Ten-week-old female C57BL/ 6-Sfrp 1+/+ mice $(n=6)$ and C57BL/6-Sfrp1-/- mice $(n=6)$ were individually housed in plastic cages with food and water provided continuously and maintained on a 12:12 light cycle. The Sfrp1 knockout allele has been described previously [34, 35]. Mammary tissue was collected from mice, flash-frozen, and stored at $-80{ }^{\circ} \mathrm{C}$ until processed for RNA isolation and used to quantify relative levels of transcripts by RT-qPCR using primers described in Additional file 2: Table S5.

\section{Human breast explant cultures}

The tissue was aseptically minced and placed on Surgifoam gelatin sponges (Ferrosan, Sueborg, Denmark) in 60-mm tissue culture dishes containing phenol-red free DMEM/F12 (Gibco) 2\% charcoal stripped serum, insulin, and gentamycin treated with vehicle $(100 \% \mathrm{EtOH})$, $10 \mathrm{nM} 17 \beta$-estradiol ( $\mathrm{E}_{2} ;$ Sigma), or $10 \mathrm{nM} \mathrm{E} \mathrm{E}_{2}$ with $1 \mu \mathrm{g} /$ $\mathrm{mL}$ rSFRP. Explant cultures were maintained for $24 \mathrm{~h}$ in $5 \% \mathrm{CO}_{2}$ air and subsequently formalin-fixed and paraffin-embedded.

\section{Progesterone receptor staining}

Immunohistochemistry (IHC) was performed on a DakoCytomation autostainer using the Envision HRP Detection system (Dako, Carpinteria, CA). Mammary tissue blocks were sectioned at $4 \mu \mathrm{m}$, deparaffinized in xylene, rehydrated in graded ethanols, and rinsed in Tris-phosphate-buffered saline (TBS). Heat-induced antigen retrieval was performed in a microwave at $98^{\circ} \mathrm{C}$ in $0.01 \mathrm{M}$ citrate buffer. After cooling for 20 min, sections were rinsed in TBS and incubated with rabbit polyclonal anti-PR 1:500, (Cell Signaling; \#8757) for $30 \mathrm{~min}$ at room temperature. Immunoreactivity was visualized by incubation with diaminobenzidine for $5 \mathrm{~min}$. Tissue sections were counterstained with hematoxylin, dehydrated through graded ethanols and xylene, and cover-slipped. Images were captured with an Olympus BX41 light microscope using (SPOT ${ }^{\mathrm{Tm}}$ Imaging Solutions, Detroit, MI). PR staining of epithelial cells was quantified using ImageJ.

\section{Statistical analyses}

The mean expression of genes in parental cells (TERTpSUPER, MCF7-SFRP1) versus SFRP1 knockdown/overexpressing cells (TERT-siSFRP1, MCF7-SFRP1) and Sfrp $1^{+/+}$ versus $S f r p 1^{-/}$mammary gland tissues were compared using paired $t$ tests.

\section{Results}

Expression patterns of biomarkers

AH lesions were classified as ductal or lobular based on histomorphologic features (Fig. 1a). Immunohistochemical membranous expression of E-cadherin (encoded by $C D H 1)$ has been used to differentiate ductal and lobular hyperplasias, with a reduced level observed in lobular lesions [36]. Consistent with these observations, ductal lesions had overall higher levels of CDH1 mRNA compared to the lobular lesions (Fig. 1b). AH tissues from two patients had both lobular and ductal characteristics and expressed levels of $C D H 1$ mRNA similar to that in ductal lesions. These results demonstrated that the differential expression of $C D H 1$ in lobular and ductal $\mathrm{AH}$ was preserved in the linear amplification and detection methods.

In an effort to define gene targets distinguishing $\mathrm{AH}$ from HNB tissues, ComBAT and LIMMA-adjusted mRNA expression levels were evaluated for several potential biomarkers (Fig. 2). Levels of mRNA for ESR1 (encoding $\mathrm{ER} \alpha$ ) were increased in $\mathrm{AH}$ while KRT5 (encoding cytokeratin 5) was decreased (Fig. 2). SFRP1 (encoding secreted frizzled-related protein 1) was among the most strongly downregulated genes in AH (Fig. 2). These results validate selected genes that have been shown to be differentially expressed in AH breast lesions reaffirming the utility of the microarray expression profiling methods. Expression of mRNA for COX2, P16/ INK4A, and KI67 (encoded by PTGS2, CDKN2A, $M K I 67$, respectively) and estrogen receptor beta (ER $\beta$, encoded by ESR2) were analyzed because prior studies suggested these as biomarkers of $\mathrm{AH}$ at greater risk of progression to breast cancer. We found that mRNA levels for these genes did not differ significantly between $\mathrm{AH}$ and HNB in either lobular or ductal subtypes of $\mathrm{AH}$.

\section{Expression signature for atypical hyperplasias}

Gene expression profiles were used to derive a signature of $\mathrm{AH}$ and to identify additional diagnostic biomarkers. Gene expression patterns in normal breast epithelium are quite variable among individuals which can obscure the modest transcriptional alterations in premalignant tissues. Therefore, a paired analysis of $\mathrm{HNB}$ and $\mathrm{AH}$ within individuals was used to detect genes that are differentially expressed in $\mathrm{AH}$ tissues. The paired analysis of AH and HNB tissues identified a total of 1039 differentially expressed probesets (LIMMA with adjusted $p$ values of $<0.05$; Additional file 2 : Table S1). By increasing the threshold (adjusted $p$ value $<0.005$ ), the signature was reduced to 99 probesets (Additional file 2: Table S2) which were used for hierarchical clustering. The data values are expressed as $\log 2$ ratios of $\mathrm{HNB} / \mathrm{AH}$ with red indicating higher expression compared to the overall mean levels across tissues and blue decreased 

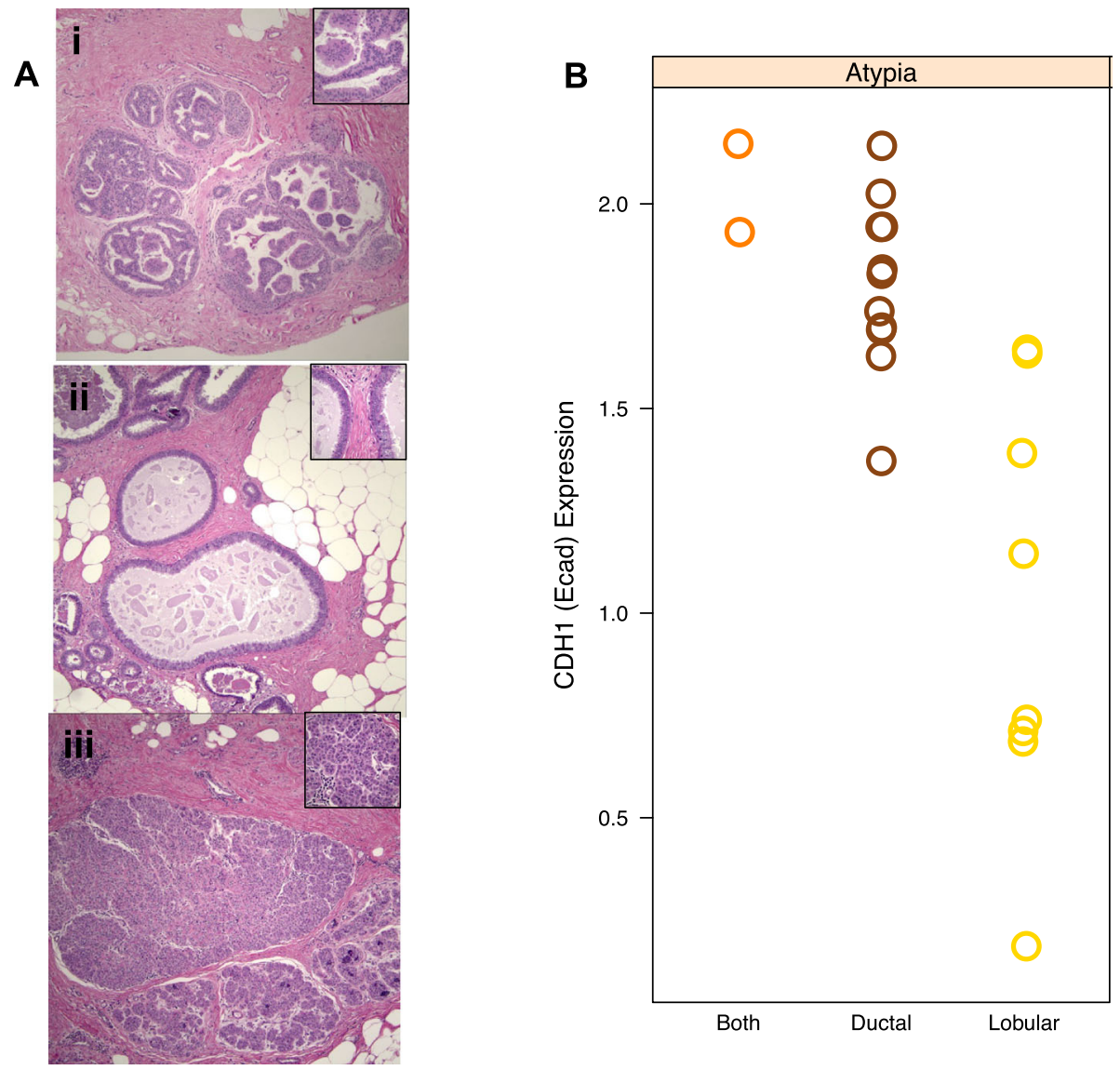

Fig. 1 Differential expression of $C D H 1$ in $A H$ and LN. a Examples of H\&E stained sections of ductal and lobular lesions that were microdissected and used for transcriptional profiling: (i) atypical ductal hyperplasia, (ii) flat epithelial atypia, and (iii) lobular carcinoma in situ. The magnification for the main images are $\times 100$ and $\times 600$ for the insert. $\mathbf{b}$ Expression of $\mathrm{CDH} 1$ is shown for atypical hyperplasias that were diagnosed as ductal, lobular, or contained components of both. The lobular atypical hyperplasias had overall lower levels of CDH1 expression compared to the ductal atypical hyperplasias

expression. Examples are GATA3, XBP1, and EVL for which mRNA levels are increased in most of the $\mathrm{AH}$ tissues. In contrast, ARRDC3, CXCL2, MAML2, and SFRP1 are expressed in HNB, but expression is significantly reduced in $\mathrm{AH}$. Two major clusters were detected that are enriched for $\mathrm{AH}$ or HNB patterns of gene expression (Fig. 3, designated "AH class" and "HNB class"). The overall pattern observed was a decrease in expression of genes in AH compared to the HNB class. Given the substantial divergence in histologic features of lobular and ductal lesions, it was anticipated that these would form sub-branches. While sub-branches are evident in the $\mathrm{AH}$ class, lobular and ductal lesions are distributed similarly in these branches suggesting that ductal and lobular lesions share a set of alterations driving their development.

While genes are selected to distinguish $\mathrm{AH}$, misclassification was anticipated due to limitations in the specificity of the gene signature and variations in molecular features underlying $\mathrm{AH}$ lesions. The clustering identifies 2 patients for which the $\mathrm{AH}$ samples cluster with the
HNB. The lesion in patient 1 (array JJ013) was an FEA. This is an intermediate lesion which may involve a single-cell layer and bears some overlap in histological features with normal tissue. Furthermore, the HNB tissue from patient 1 (JJ014) is adjacent to the FEA tissue in the cluster. The HNB tissue in patient 4 (JJ016) is adjacent to the clustering of the LCIS lesion (JJ015) suggesting that the molecular features are largely benign despite the morphologic features. Conversely, the HNB tissue for patient 15 clustered with the $\mathrm{AH}$ tissues (DJJ030, DJJ029, respectively). The HNB and AH tissues from patient 15 are adjacent to one another in the clustering suggesting that the HNB tissue shared underlying molecular alterations despite the differences in histologic features. The two samples from patient 15 form a branch in the cluster with the ADH from patient 14 (DJJ027). Patient 14 was diagnosed with DCIS in the contralateral breast 6 months later raising the possibility that the pattern of expression in this branch represents increased likelihood for progression. In each of these 


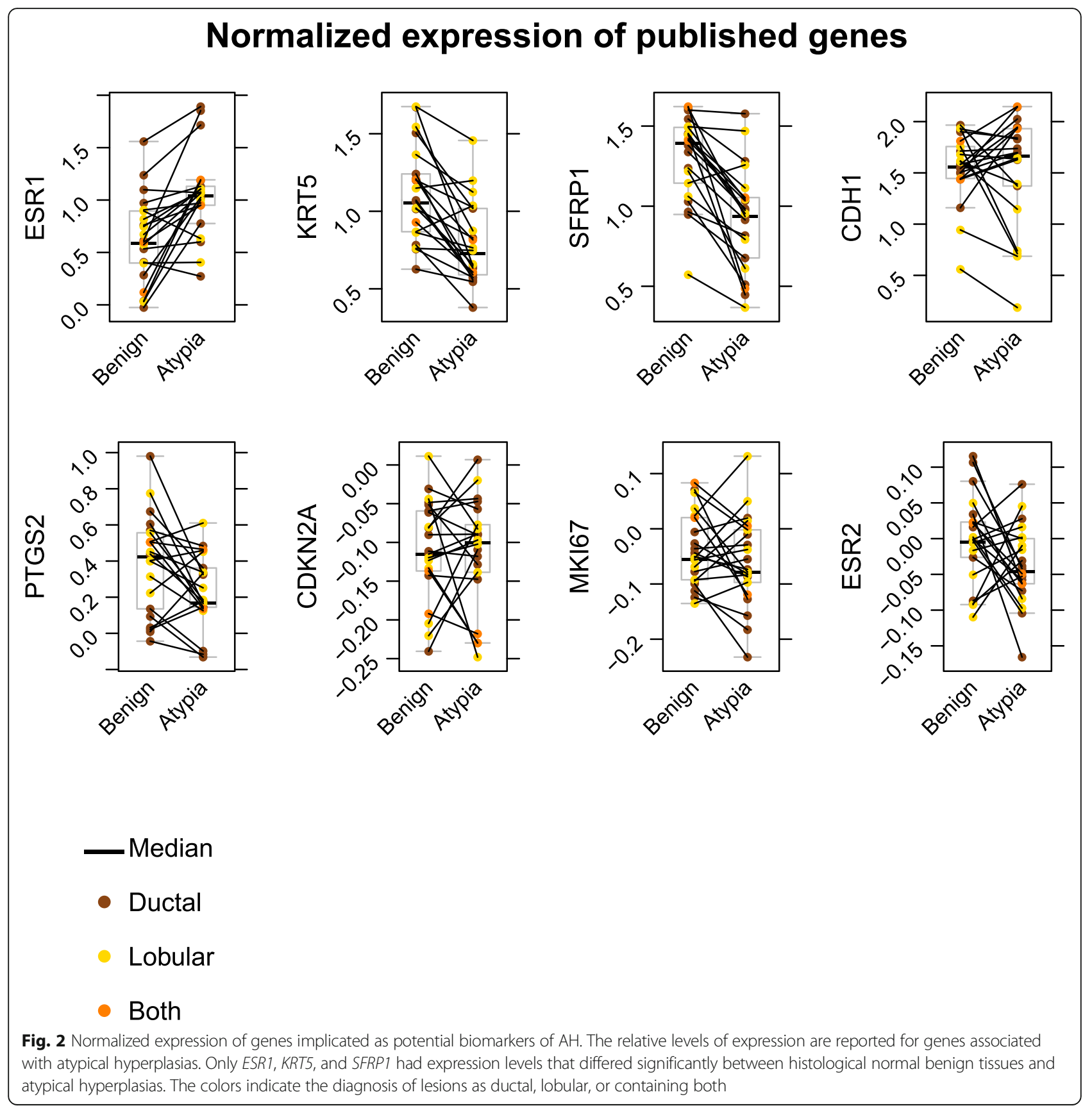

patients $(1,4,15)$, the $\mathrm{AH}$ is adjacent to the HNB in the cluster providing support for the reproducibility gene expression patterns within individual patients. Overall, the set of genes distinguishes HNB tissues for $81 \%$ of patients (Fig. 3; 17/21 in "HNB class"), providing biomarkers that can be used to aid discrimination of AH.

The data were also analyzed using the paired model with blocking for the histopathology of lesions (ductal vs lobular) to identify potential biomarkers. This identified 11 genes that differed consistently in mRNA levels between HNB and AH (Fig. 4). Both KIT and PROM1 (encoding CD133) have been associated with stem cell phenotypes and exhibit decreased expression in $\mathrm{AH}$. The chemokines CXCL2 and CCL28 along with secreted leukocyte peptidase inhibitor (SLPI) participate in inflammatory responses and were among the differentially expressed genes. While inflammation contributes to oncogenic progression, both were downregulated in atypia. Similarly, the PI-3-kinase PIK3C2G was consistently decreased in $\mathrm{AH}$ along with genes involved in ion transport (GABRP, SLC39A6). The increase in sorbitol dehydrogenase $(S O R D)$ suggests metabolic changes, but the levels 


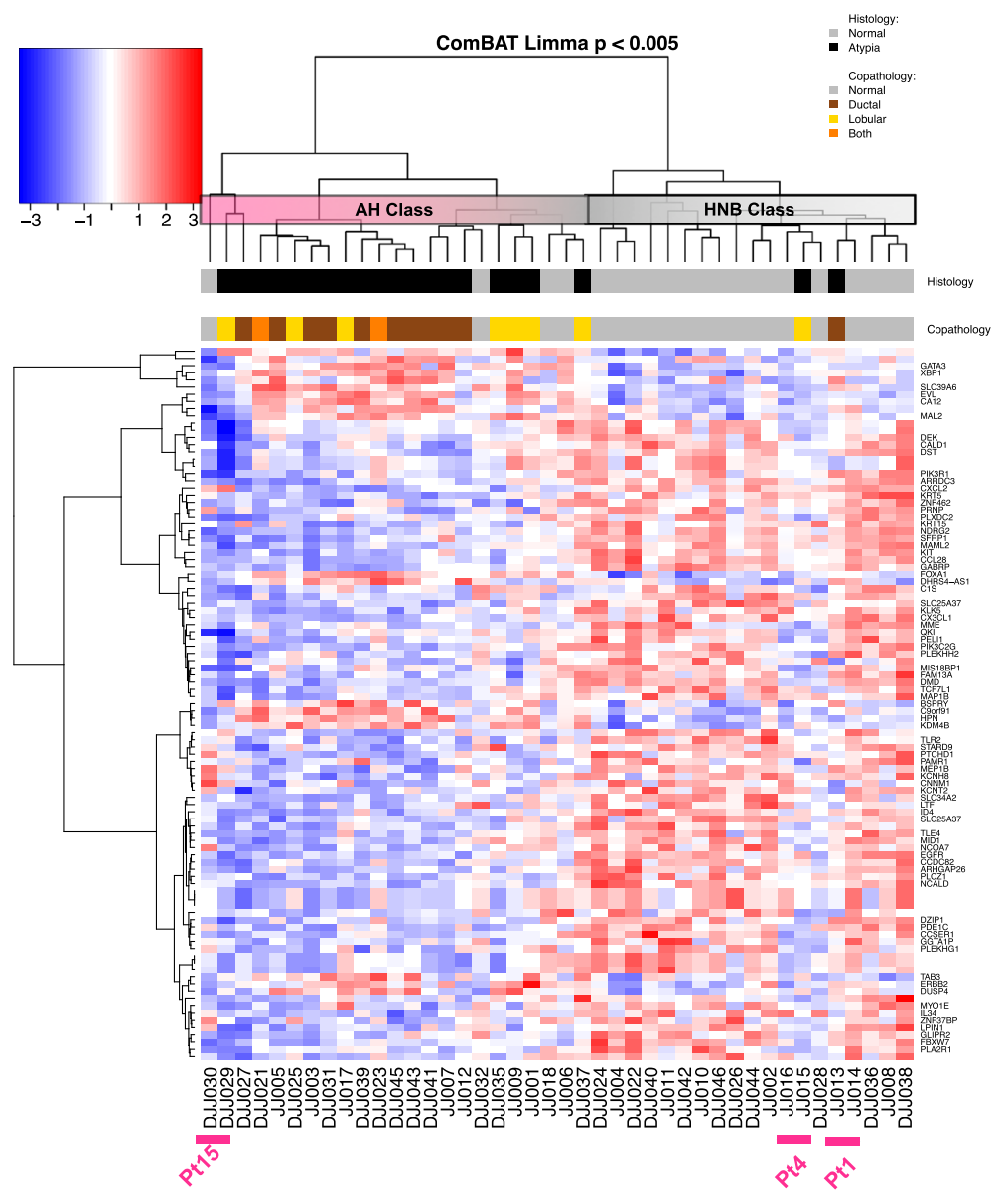

Fig. 3 Hierarchical clustering of differentially expressed genes. Genes that were differentially expressed at $p<0.005$ were selected and clustered using AGNES. Two main clusters were defined that were enriched for either histologically normal benign tissue (HNB class) or histologically AH (AH class). This gene set did not separate the ductal and lobular subtypes of AH. Two AH samples had expression patterns similar to the histologically normal tissues. Samples JJ13 and JJ15 were diagnosed as FEA and LCIS, respectively. Both clustered adjacent to the histologically normal tissue from the same patient (JJ14 and $J J 16$, respectively) suggesting that these are true benign tissues. In contrast, DJJ030 is histologically normal tissue, but clusters adjacent to the LCIS tissue (DJJ029) from patient \#15 suggesting that the tissue harbors genetic alterations driving the gene expression but has not yet acquired the histological architecture of AH. The data values are expressed as log base 2 ratios of HNB/AH with red indicating increased expression compared to the overall mean levels across tissues and blue decreased levels

were variable making it unlikely to be a reliable biomarker. The decreased levels of NKBIZ (encoding an inhibitor of NFkB) together with increases in ESR1 may combine to increase sensitivity to estrogen-stimulated proliferation in $\mathrm{AH}$.

Prediction Analysis of Microarrays (PAM) was used as an alternate algorithm to identify gene expression signatures. The ComBat-normalized data from the LIMMA paired model $(p<0.05)$ was analyzed and identified a PAM signature of 139 probesets (Additional file 2: Table S3). The intersection of the AGNES and PAM signatures identified 43 genes common to both methods (Table 2). The keratins (KRT5 and KRT15) are among this group as well as luminal markers (KIT, FOXA1). SFRP1 was also identified in the signature of both prediction algorithms. These independent methods for class prediction provide a reduced set of biomarkers to aid diagnosis of $\mathrm{AH}$.

\section{Pathway analysis}

Gene expression patterns were overlaid onto proteinprotein interaction databases to detect pathways that are altered in $\mathrm{AH}$. Probesets that were differentially expressed between the $\mathrm{AH}$ and $\mathrm{HNB}$ tissues (representing 812 genes) formed a zero-order network of 61 differentially expressed genes (Fig. 5) that had direct interactions (61 seeds, 90 edges). The zero-order network reveals extensive interactions of genes with ESR1, RHOB, $A R$, and EGFR receptors (ERBB2, $E R B B 3, E R B B 4)$ which form central nodes. Expression of ERB-B receptors (ERBB2, ERBB3, $E R B B 4)$ are elevated and have a total of 23 edges. In contrast, expression of ligands (TGFA, EGF, NRG1) and EGFR 


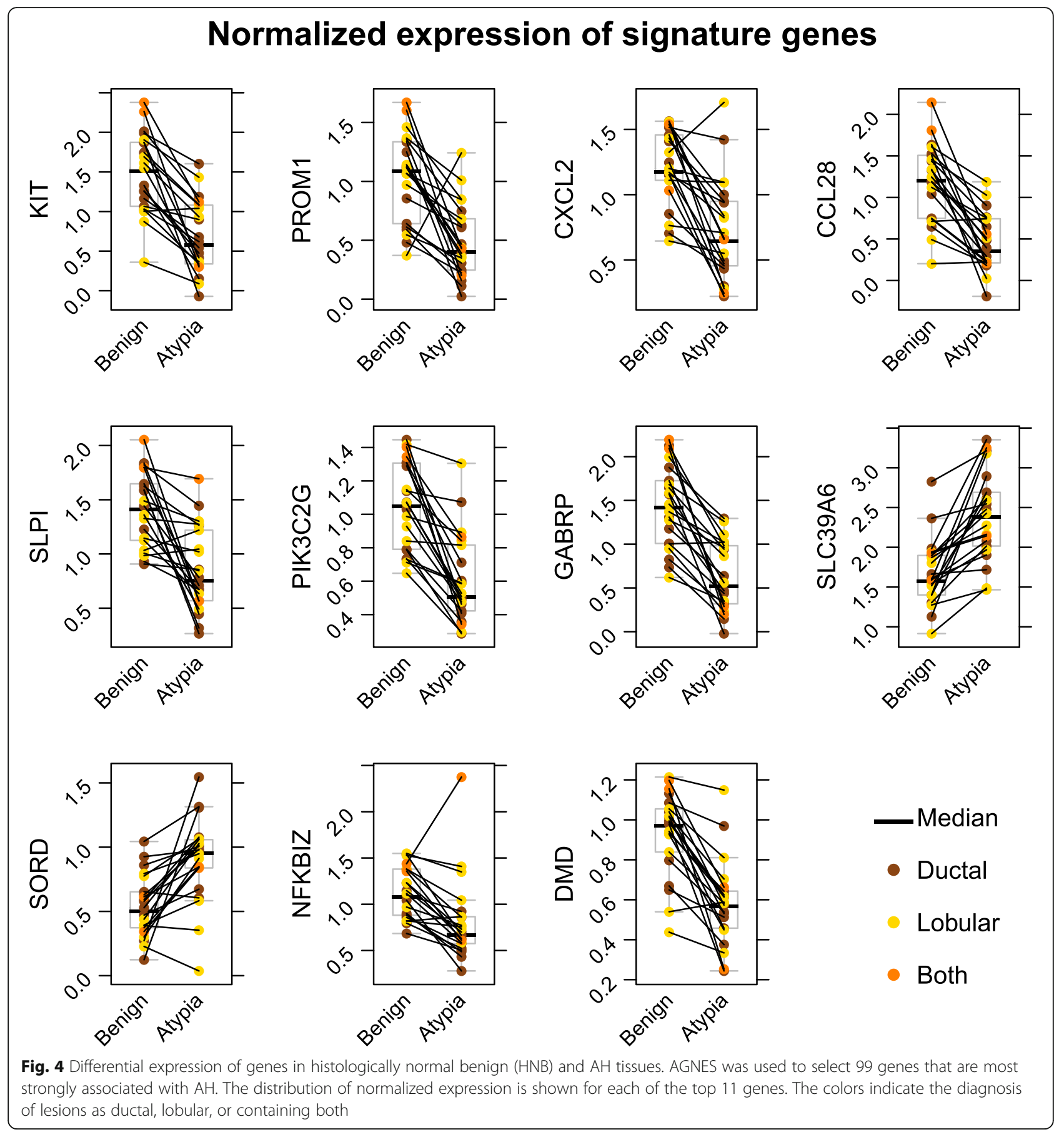

are decreased. $R H O B$ levels were also elevated in $\mathrm{AH}$ lesions and form a separate node with a group of genes that are all downregulated. Increased expression of ESR1 is consistent with prior studies; however, the associated increase in expression of $K D M 4 B, X B P 1$, and $N E L B$ suggests a subnetwork that may act in concert with $\mathrm{ER} \alpha$. The androgen receptor $(A R)$ is also elevated in $\mathrm{AH}$ lesions and forms a subnetwork. Although FOXA1 and GATA3 are shown as interactors with only $A R$ based on the STRINGS database, both genes are known to collaborate with ER $\alpha$.

The 1st-order networks were also analyzed to identify broader pathways that may be over-represented and indicate broader alterations in signaling pathways. The major network had 306 genes/seeds that were differentially expressed generating 3849 edges and 2364 nodes. Additional subnetworks were detected but had only 1 differentially expressed seed in each. Within the major 
Table 2 Differentially expressed genes identified in both AGNES and PAM signatures

\begin{tabular}{|c|c|}
\hline AFFYMETRIX_EXON_ID & Gene name \\
\hline 7903414 & Amylase, alpha 1A (salivary) (AMY1A) \\
\hline 7927058 & Unknown \\
\hline 7951133 & $\begin{array}{l}\text { Mastermind-like transcriptional coactivator } 2 \\
\text { (MAML2) }\end{array}$ \\
\hline 7954208 & $\begin{array}{l}\text { Phosphatidylinositol-4-phosphate 3-kinase } \\
\text { catalytic subunit type } 2 \text { gamma (PIK3C2G) }\end{array}$ \\
\hline 7963427 & Keratin 5 (KRT5) \\
\hline 7976726 & Enah/Vasp-like (EVL) \\
\hline 7977621 & NDRG family member 2 (NDRG2) \\
\hline 7978706 & Forkhead box A1 (FOXA1) \\
\hline 7989501 & Carbonic anhydrase 12 (CA12) \\
\hline 7996027 & C-X3-C motif chemokine ligand 1 (CX3CL1) \\
\hline 8015337 & Keratin 15 (KRT15) \\
\hline 8022927 & Solute carrier family 39 member 6 (SLC39A6) \\
\hline 8024909 & Lysine demethylase 4B (KDM4B) \\
\hline 8041644 & $\begin{array}{l}\text { Pleckstrin homology, MyTH4 and FERM } \\
\text { domain containing H2 (PLEKHH2) }\end{array}$ \\
\hline 8075182 & X-box binding protein 1 (XBP1) \\
\hline 8086607 & Lactotransferrin (LTF) \\
\hline 8094441 & Solute carrier family 34 member 2 (SLC34A2) \\
\hline 8095110 & $\begin{array}{l}\text { KIT proto-oncogene receptor tyrosine } \\
\text { kinase }(\mathrm{KIT})\end{array}$ \\
\hline 8100994 & C-X-C motif chemokine ligand 2 ( $C X C L 2)$ \\
\hline 8106098 & Microtubule-associated protein 1B (MAP1B) \\
\hline 8108873 & Rho GTPase activating protein 26 (ARHGAP26) \\
\hline 8109926 & $\begin{array}{l}\text { Gamma-aminobutyric acid type A receptor } \\
\text { pi subunit (GABRP) }\end{array}$ \\
\hline 8111932 & C-C motif chemokine ligand 28 (CCL28) \\
\hline 8113073 & Arrestin domain containing 3 (ARRDC3) \\
\hline 8117120 & Inhibitor of DNA binding 4, HLH protein (ID4) \\
\hline 8119076 & Unknown \\
\hline 8121861 & Nuclear receptor coactivator 7 (NCOA7) \\
\hline 8124144 & DEK proto-oncogene (DEK) \\
\hline 8127234 & Dystonin (DST) \\
\hline 8130556 & $\begin{array}{l}\text { Uncharacterized LOC100129518 } \\
\text { (LOC100129518) }\end{array}$ \\
\hline 8136347 & Caldesmon 1 (CALD1) \\
\hline 8145291 & Solute carrier family 25 member 37 (SLC25A37) \\
\hline 8150076 & Dual specificity phosphatase 4 (DUSP4) \\
\hline 8150428 & Secreted frizzled-related protein 1 (SFRP1) \\
\hline 8152119 & Neurocalcin delta (NCALD) \\
\hline 8155359 & $\begin{array}{l}\text { Contactin-associated protein-like 3B } \\
\text { (CNTNAP3B) }\end{array}$ \\
\hline 8155460 & $\begin{array}{l}\text { Contactin-associated protein-like } 3 \\
\text { pseudogene } 2 \text { (CNTNAP3P2) }\end{array}$ \\
\hline 8155540 & Contactin-associated protein-like 3B \\
\hline
\end{tabular}

Table 2 Differentially expressed genes identified in both AGNES and PAM signatures (Continued)

\begin{tabular}{ll}
\hline AFFYMETRIX_EXON_ID & Gene name \\
\hline 8161460 & (CNTNAP3B) \\
8166447 & $\begin{array}{l}\text { Contactin-associated protein-like 3B } \\
\text { (CNTNAP3B) }\end{array}$ \\
8168727 & Patched domain containing 1 (PTCHD1) \\
8171297 & Unknown \\
8171921 & Midline 1 (MID1) \\
\hline & Dystrophin (DMD) \\
\hline
\end{tabular}

network with 306 seeds, there was over-representation of five KEGG pathways with $p<10^{-25}$ (Table 3). The alterations in ERBB2 and WNT signaling overlap extensively with the pathways in cancer.

\section{Genes in the signature regulated by SFRP1 expression} SFRP1 is best known for its antagonism of the WNT pathway. However, it binds other proteins, such as RANKL and thrombospondin, and its loss has been demonstrated to affect signaling of other critical pathways involving ER $\alpha$, TGFB receptor, and p53 through less well-studied mechanisms. Therefore, loss of expression in AH may directly influence genes differentially expressed in $\mathrm{AH}$.

The 76N-Tert cells express SFRP1 and, therefore, were used to test whether knockdown of SFRP1 (TERTsiSFRP1) may drive a set of genes that are differentially expressed in AH. The levels of SFRP1 in TERT-siSFRP1 cells are shown in Additional file 1: Figure S1. A total of 31 genes within the PAM signature (Additional file 2: Table S3) were selected to test for differential expression in the TERT-siSFRP1 vs TERT-pSUPER cells. In total, 6 genes with decreased expression in $\mathrm{AH}$ tissues (SLPI, MAML2, ARRDC3, PIK3C2G, KRT15, CXCL2) were also decreased by knockdown of SFRP1 (TERT-siSFRP1 cells; Fig. 6a, b). Conversely, 6 genes for which mRNA levels were increased in AH tissues (SGK3, FOXA1, AGR3, $M L P H, E V L, K D M 4 B$ ) also had increased expression in TERT-siSFRP1 cells compared to the TERT-pSUPER control cells (Fig. 6b). Among 19 other genes from the PAM signature, mRNA levels for 16 genes were unaffected by knockdown of SFRP1 while expression was the opposite of that observed in AH for 3 genes. ERBB4 was also tested because it is part of the zero-order network (Fig. 5) and had been implicated in regulation by SFRP1. Knockdown of SFRP1 resulted in increased ERBB4 mRNA consistent with the higher levels in AH compared to HNB (Fig. 6a, b). These results suggest that decreased expression of SFRP1 alters a network of genes in AH.

We examined the expression of the 13 genes in mammary tissues from Sfrp1-/- mice to confirm dependence on SFRP1 and determine if the network is conserved 


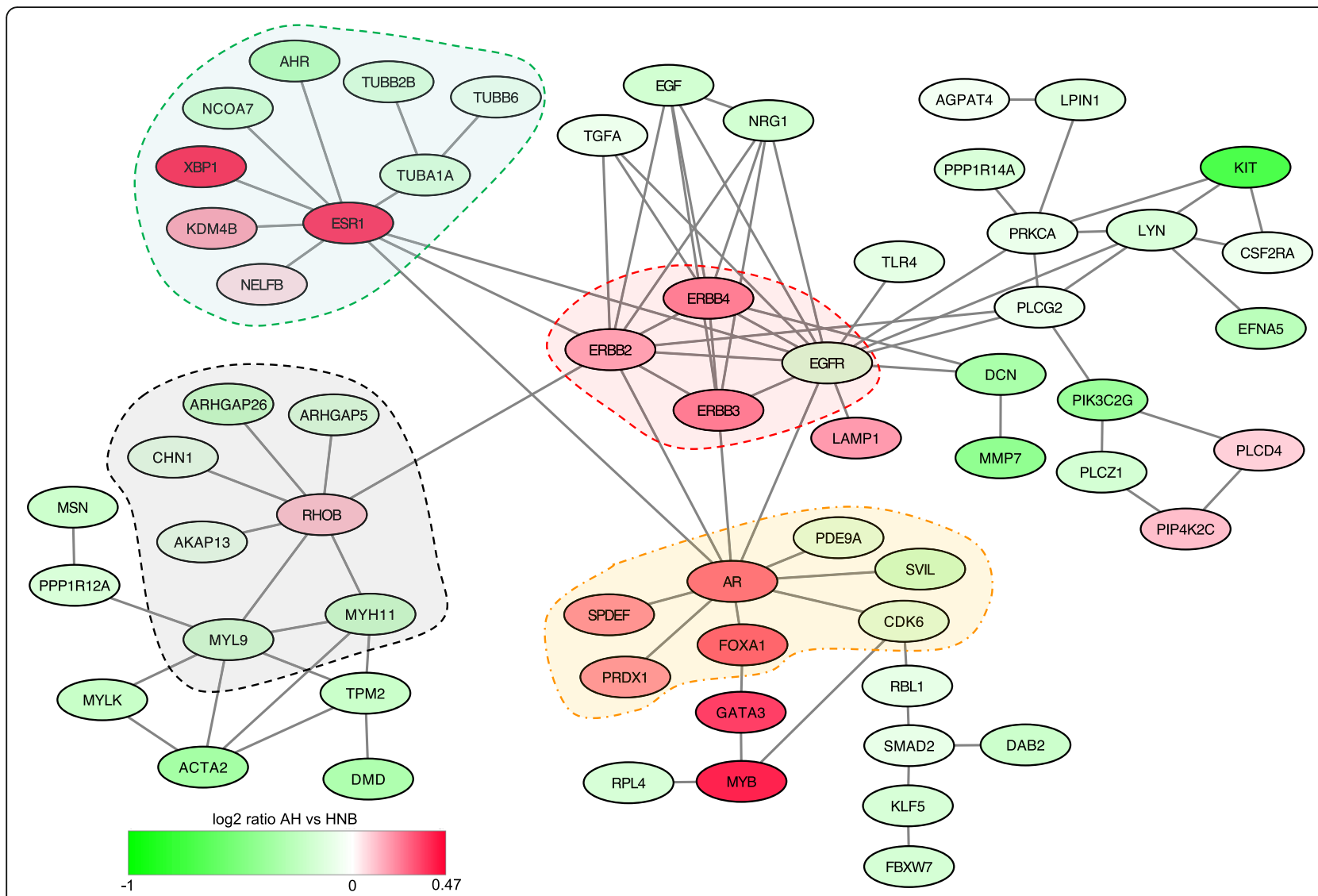

Fig. 5 Zero-order network formed by genes that are differentially expressed in histologically normal benign (HNB) and AH tissues. A network of protein interactions was constructed using 812 genes that were differentially expressed between $A H$ and HNB tissues. The ERB-B genes (ERBB2, $E R B B 3, E R B B 4, E G F R$ ) define a central node connected to three major nodes associated with elevated expression of ESR1, $A R$, and $R O H B$ in $A H$ compared to HNB tissues. The data are presented as ratios with red indicating increased expression in AH tissues compared to HNB. Dotted lines encompassing major nodes indicate zero-order subnetworks

across species (Fig. 6c). Similar to AH in humans (Fig. 6a), loss of Sfrp1 in mice resulted in reduced expression of 3 genes compared to the wild-type mice (Slpi, Arrdc3, Pik3c2g) and increased expression of 3 genes (Foxa1, Erbb4, $K d m 4 b$ ). Therefore, a portion of the SFRP1-regulated network was conserved in this mouse model. To explore if re-expression of SFRP1 could reverse the changes, we used MCF7 breast cancer cells which lack SFRP1 expression and compared effects of over-expression (MCF7-SFRP1 vs MCF7-pCDNA; see Additional file 1: Figure S1). Constitutive expression of SFRP1 increased 5 genes (SLPI, MAML2, ARRDC3, PI3KC2G, KRT15) that were downregulated in AH and TERT-siSFRP1 cells and reduced expression of 3 genes (SGK3, FOXA1, AGR3) that were upregulated in AH and TERT-siSFRP1 cells (Fig. 6d). These data demonstrate the presence of an SFRP1-regulated gene network in both human tissues and cell lines that is also conserved in mice.

Enhanced estrogen signaling and loss of SFRP1 expression are common features within the gene expression signature in $\mathrm{AH}$, but it is unclear if these are related mechanistically or are simply complementary alterations acquired during development of AH. Therefore, we wanted to determine if SFRP1 protein levels control responsiveness to estrogen stimulation. Explant cultures of normal breast tissue from 5 subjects were treated with $17 \beta$-estradiol $\left(E_{2}\right)$ in the presence of recombinant SFRP1 (rSFRP) protein or vehicle control for $24 \mathrm{~h}$ to determine if expression of progesterone receptor (PR) was altered (Fig. 7). The percentage of breast epithelial cells expressing PR was increased in response to $\mathrm{E}_{2}$ treatment in the 5 patients. Addition of rSFRP1 suppressed the response to $\mathrm{E}_{2}(p=0.01)$. These results demonstrate that SFRP can influence $\mathrm{E}_{2}$-stimulated responses in normal breast tissues and that its loss in $\mathrm{AH}$ may affect estrogen signaling.

\section{Discussion}

The pathways disrupted in $\mathrm{AH}$ offer insights into the early molecular changes that are associated with increased risk of malignancy. Prior analyses of AH have most often utilized regions of $\mathrm{AH}$ that co-exist with carcinomas $[17,18]$. This approach was necessary because tissues from percutaneous core biopsies and excisional biopsies with $\mathrm{AH}$ in 
Table 3 Pathways over-represented in the first-order 812 gene network

\begin{tabular}{|c|c|c|c|c|c|}
\hline Pathway & Total & Expected & Hits & $p$ value & FDR \\
\hline Pathways in cancer & 310 & 80.9 & 197 & $6.53 \mathrm{E}-47$ & $1.42 \mathrm{E}-44$ \\
\hline ErbB signaling pathway & 87 & 22.7 & 70 & 1.35E-26 & 1.47E-24 \\
\hline Chronic myeloid leukemia & 73 & 19.1 & 62 & $3.38 \mathrm{E}-26$ & $2.45 E-24$ \\
\hline HTLV-I infection & 199 & 52 & 121 & $5.30 E-26$ & $2.78 \mathrm{E}-24$ \\
\hline WNT signaling pathway & 144 & 37.6 & 97 & $6.41 \mathrm{E}-26$ & $2.78 \mathrm{E}-24$ \\
\hline Focal adhesion & 200 & 52.2 & 117 & 4.23E-23 & $1.53 \mathrm{E}-21$ \\
\hline Pancreatic cancer & 69 & 18 & 56 & $8.10 \mathrm{E}-22$ & $2.51 \mathrm{E}-20$ \\
\hline Neurotrophin signaling pathway & 123 & 32.1 & 82 & 1.39E-21 & $3.78 \mathrm{E}-20$ \\
\hline Prostate cancer & 87 & 22.7 & 64 & $1.27 \mathrm{E}-20$ & 3.07E-19 \\
\hline Colorectal cancer & 49 & 12.8 & 43 & $1.21 \mathrm{E}-19$ & 2.63E-18 \\
\hline Osteoclast differentiation & 119 & 31.1 & 77 & $3.84 \mathrm{E}-19$ & $7.58 \mathrm{E}-18$ \\
\hline Acute myeloid leukemia & 57 & 14.9 & 47 & $4.98 \mathrm{E}-19$ & $9.01 \mathrm{E}-18$ \\
\hline Hepatitis C & 100 & 26.1 & 68 & 8.76E-19 & $1.46 \mathrm{E}-17$ \\
\hline T cell receptor signaling pathway & 98 & 25.6 & 67 & $1.02 \mathrm{E}-18$ & $1.58 \mathrm{E}-17$ \\
\hline Melanogenesis & 101 & 26.4 & 68 & $2.02 \mathrm{E}-18$ & 2.92E-17 \\
\hline Regulation of actin cytoskeleton & 182 & 47.5 & 102 & $2.39 \mathrm{E}-18$ & $3.24 \mathrm{E}-17$ \\
\hline Chagas disease (American trypanosomiasis) & 89 & 23.2 & 62 & 4.82E-18 & $6.15 \mathrm{E}-17$ \\
\hline MAPK signaling pathway & 265 & 69.2 & 132 & $1.51 \mathrm{E}-17$ & $1.82 \mathrm{E}-16$ \\
\hline B cell receptor signaling pathway & 75 & 19.6 & 54 & 7.04E-17 & $8.04 \mathrm{E}-16$ \\
\hline Gap junction & 89 & 23.2 & 60 & $1.99 \mathrm{E}-16$ & $2.16 \mathrm{E}-15$ \\
\hline Renal cell carcinoma & 60 & 15.7 & 46 & $2.51 \mathrm{E}-16$ & $2.60 \mathrm{E}-15$ \\
\hline Epstein-Barr virus infection & 91 & 23.8 & 60 & $9.93 \mathrm{E}-16$ & $9.79 \mathrm{E}-15$ \\
\hline Cell cycle & 124 & 32.4 & 74 & 1.37E-15 & 1.30E-14 \\
\hline Axon guidance & 118 & 30.8 & 71 & $2.90 \mathrm{E}-15$ & $2.62 \mathrm{E}-14$ \\
\hline Toll-like receptor signaling pathway & 97 & 25.3 & 62 & $3.02 \mathrm{E}-15$ & $2.62 \mathrm{E}-14$ \\
\hline Glioma & 65 & 17 & 47 & $5.85 \mathrm{E}-15$ & $4.88 \mathrm{E}-14$ \\
\hline Herpes simplex infection & 103 & 26.9 & 64 & 7.95E-15 & $6.39 \mathrm{E}-14$ \\
\hline
\end{tabular}

women without cancer are often exhausted for histopathological diagnosis. The recovery and quality of RNA from formalin-fixed, paraffin-embedded (FFPE) tissues is poor and limits the methods for genome-wide transcriptional profiling to 3 ' ends of mRNA for prior studies [37]. However, AH adjacent to tumors may already harbor alterations similar to the tumor cells [38] which can confound results. To overcome these limitations, we optimized methods for RNA isolation and amplification to allow reproducible analysis of transcriptional profiles using microdissected $\mathrm{AH}$ lesions from women without a prior history of breast cancer.

Using these methods, we confirmed increases in mRNA levels of ESR1 and decreases in KRT5 as were previously reported using immunohistochemical detection of these proteins [7], as well as differences in CDH1 (encoding E-cadherin) in ductal and lobular $\mathrm{AH}$ [36]. Paired analysis of $\mathrm{AH}$ and $\mathrm{HNB}$ tissues within individuals identified a 99-gene signature that discriminated $90 \%$ of the AH and $81 \%$ of the HNB (Fig. 3). HNB from 4 individuals clustered with the "AH class" which may reflect false-positives. Alternatively, it may also reflect a limitation of using tissue that is adjacent to $\mathrm{AH}$ lesions which can harbor genetic alterations present in the $\mathrm{AH}[39,40]$. Field effects have been reported at margins of $2 \mathrm{~cm}$ [41]. This is especially likely for patient 15 for whom the HNB clustered next to the $\mathrm{AH}$ suggesting similarity at the molecular level. Conversely, AH from patients 1 and 4 were in the HNB class which may indicate false negatives, but may also indicate lesions that express the morphologic features of $\mathrm{AH}$ yet have a molecular signature more similar to HNB. The lesion from patient 1 was an FEA which is consistent with a low potential for malignant progression. These inherent uncertainties in diagnosis lead to an underestimate of the transcriptional changes in $\mathrm{AH}$. Conversely, the differences in expression detected using the 99-gene signature reflect a robust set of biomarkers that can aid concordance in the diagnosis of $\mathrm{AH}[42,43]$. 

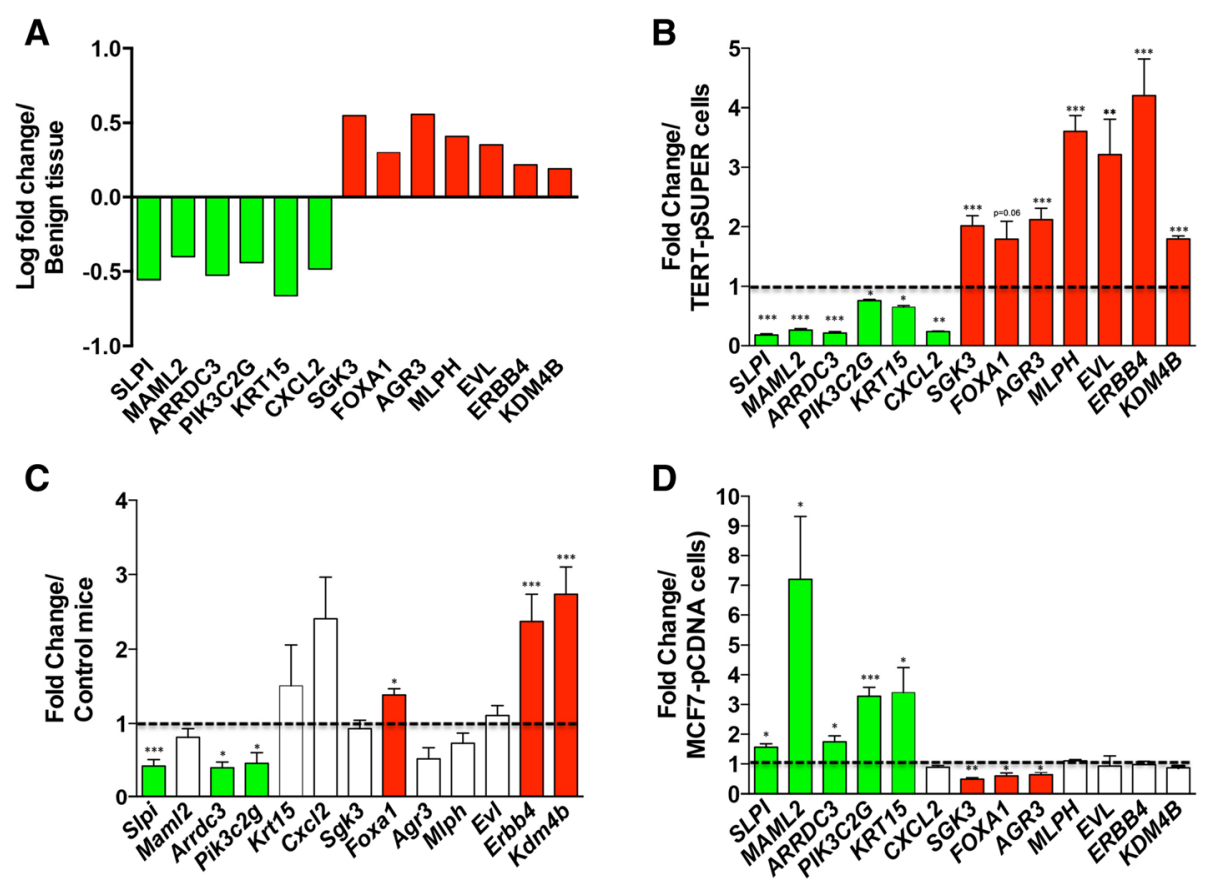

Fig. 6 Expression of genes in AH and regulation by SFRP1. Genes associated with AH were identified by AGNES and PAM were examined for regulation by SFRP1. a The relative expression of the genes in AH are shown. Green indicates genes with decreased expression in $\mathrm{AH}$ relative to the HNB tissues and red indicates those with increased expression. $\mathbf{b}$ The effect of SFPR1 knockdown on gene expression was analyzed in a cell line derived from normal breast epithelium and immortalized with telomerase (76NTERT cells). Relative levels of transcripts were determined by RT-qPCR in TERT-siSFRP1 cells and the TERT-pSUPER vector control cells. c Similarly, mRNA levels of the genes was compared by RT-qPCR in mouse mammary glands derived from Sfrp $1^{-/-}$and control Sfrp $1^{+/+}$mice. d Breast cancer cells overexpressing SFRP1 (MCF7-SFRP1) and control cells (MCF7-pCDNA) were also compared for relative levels of gene expression by RT-qPCR. The level of SFRP1 mRNA was normalized to the amplification of ACTB mRNA, which was performed in parallel wells for each cell line or tissue. Bars represent mean \pm SEM SFRP1/ACTB and are expressed as relative expression of control TERT-pSUPER (b), control mice (c), and MCF7-pCDNA (d). Genes where loss of SFRP1 results in decreased expression are shown in green, those increased are shown in red, and those which are unchanged are shown in white ${ }^{*} p<0.05$, ${ }^{* *} p<0.01$, and ${ }^{* *} p<0.001$ (significantly different from control using Student's $t$ test)

Within the signature, there were increases in genes associated with the luminal (e.g., ESR1, GATA3, KRT18) and decreases in genes associated with the basal breast epithelium (e.g., KRT5, TP63, ACTA2). This may reflect a clonal expansion neoplastic luminal cells in $\mathrm{AH}$ which could result in a decrease in the apparent expression of genes that are markers of the basal epithelium. However, there were also significant decreases in genes associated with the normal luminal epithelium. Immunolocalization of c-KIT is reported in normal breast epithelial cells $[44,45]$ with loss of c-KIT in low-grade breast cancers. ELF5 has been associated with differentiation of the luminal epithelium, and its expression is decreased significantly in luminal A, luminal B, and HER2 subtypes of breast cancer [46]. Levels of these genes associated with luminal epithelium were decreased significantly in the $\mathrm{AH}$ samples (Fig. 4; Additional file 2: Table S3). In addition, increased levels of immunohistochemical staining for $E R \alpha$, GATA3, and FOXA1 proteins have been reported in early breast lesions $[8,37,47]$ which is consistent with increased expression of mRNA detected in AH (Figs. 2, 3, and 4, Additional file 2: Table S3). Therefore, the signature is not solely due to the increase in luminal epithelium in $\mathrm{AH}$ tissues. The expression analyses of $\mathrm{AH}$ may represent more complex cellular phenotypes that are not characteristic of either the basal or luminal cells within normal breast tissues. Transcriptional profiling of mouse mammary and human breast tissues have also revealed an unexpected complexity of cellular identities and lineages [48-50]. Therefore, it is possible that the gene signature in AH may represent an enrichment of a subclass of breast epithelial cells.

Models of breast progression generally support the evolution of invasive ductal and lobular carcinomas along two distinct lineages of lesions [51]. This is based on the differences in genomic alterations and gene expression profiles in invasive ductal and lobular carcinomas [52, 53]. A comprehensive analysis identified mutational hallmarks distinguishing invasive lobular carcinomas [54]. However, we failed to observe a distinction in expression profiles from ductal and lobular AH by hierarchical clustering (Fig. 3). Similar numbers of AH were profiled for 


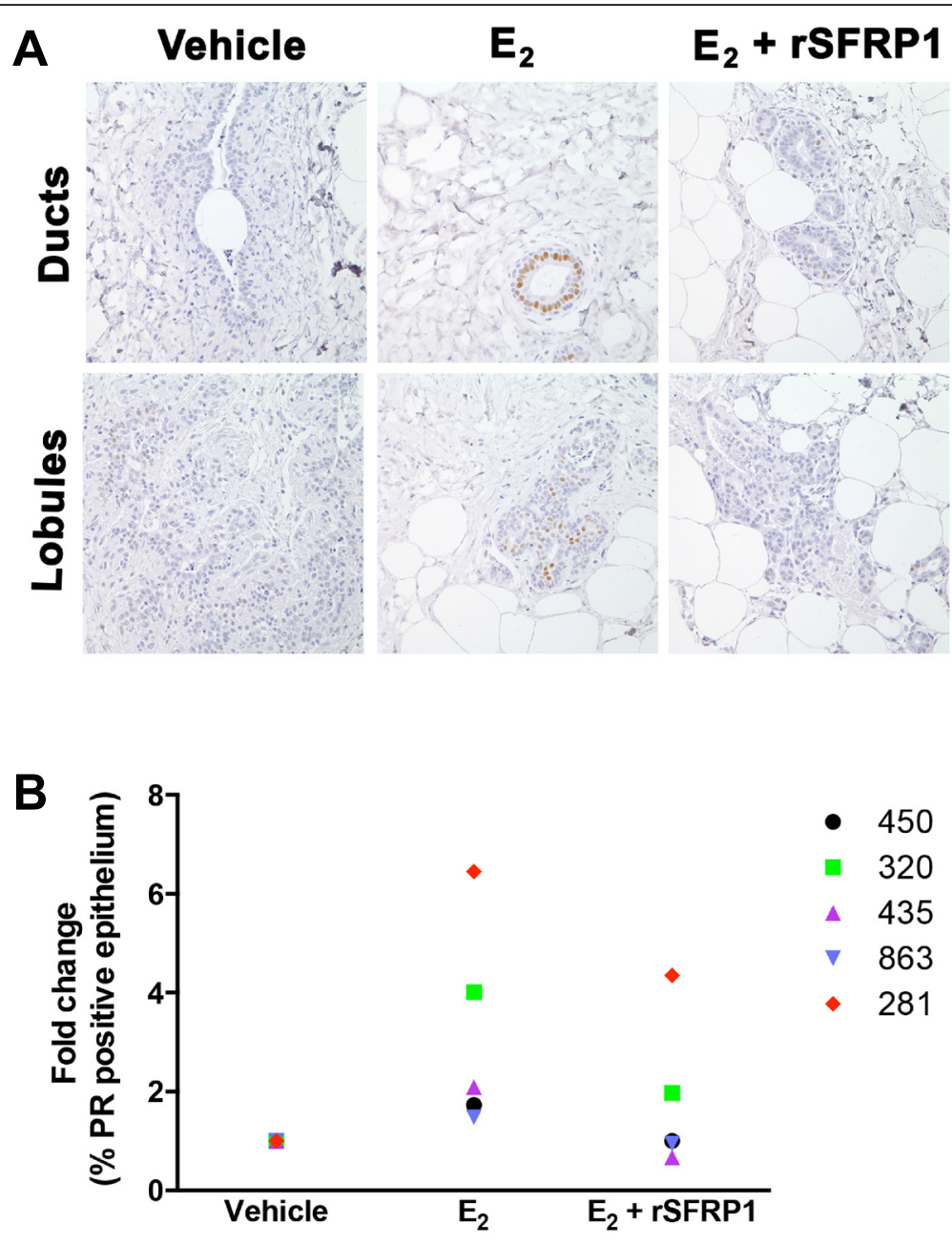

Treatments

Fig. 7 Effect of SFRP1 on estrogen-induced expression of progesterone receptor (PR) in breast explant cultures. Normal breast tissues from women undergoing reduction mammoplasty were placed in culture and treated with vehicle, 17ß-estradiol $\left(E_{2}\right)$ or $E_{2}$ together with rSFRP1 (E2 + SFRP1). Immunohistochemical staining was used to detect cells expressing PR (brown chromogen). (a) Representative images from Subject 435 were captured at $400 \times$ images for staining in ducts and lobule for one patient. (b) PR-stained cells were counted in each treatment group for 5 different subjects and the fold change in PR-positive cells is shown for each patient. Responses to $E_{2}$ varied among individuals but SFRP1 diminished the effect of $E_{2}$ in each case $\left(E_{2}\right.$ vs $\left.E_{2}+r S F R P 1, p<0.01\right)$

both the ductal and lobular histological classes, and expression of E-cadherin (CDH1) mRNA levels confirmed the classifications. This raises the possibility that alterations in a common set of pathways contribute to atypical hyperplasias in both ductal and lobular epithelial cells. The subsequent alterations observed during progression toward ductal and lobular carcinomas may be defined by vulnerabilities that differ in the ductal and lobular cell types.

The network analyses provide further insights into the spectrum of molecular changes detected in $\mathrm{AH}$ and render the breast epithelium at heightened risk of breast cancer. Among genes that are differentially expressed in $\mathrm{AH}$ (0-order network), we observed a network involving ESR1, ERB-B receptors and AR/GATA3/FOXA1 (Fig. 5).
Prior studies examining transcriptional profiles of benign hyperplasias also identified increased expression of ESR1 and $E R B B$ genes [8, 47]. A study of matched normal, early neoplasia and carcinoma from a cohort of 25 women identified elevated expression of ERBB2, FOXA1, and GATA3 [37]. This study by Brunner et al. included only 7 cases of early neoplasias without synchronous cancer which likely limits the threshold for detecting changes in $\mathrm{AH}$. Nonetheless, they observed elevated expression of $K D M 4 B, X B P 1, A R, M Y B$, and SPDEF in early neoplasias compared to normal [37] which were also elevated in our profile (Additional file 2: Table S1). $K D M 4 B$ and $X B P 1$ are part of the interaction network with ESR1 while SPDEF, FOXA1, GATA3, and MYB are 
linked to $A R$ (Fig. 5). Therefore, our data is consistent with and extends the information provided by prior studies. As the samples used in our study were from $\mathrm{AH}$ in patients without breast cancer, these genes define alterations in pathways that may contribute to the formation of premalignant breast lesions. The prominent role of estrogen signaling in the network is consistent with the success of anti-estrogen treatments in preventing progression of AH to carcinomas $[55,56]$.

Signaling networks in AH may also include mRNAs and proteins where levels are unchanged, but their activities are stimulated by interactions with other proteins causing post-translational modifications (e.g., by phosphorylation) and formation of larger complexes. Therefore, the 1storder networks were also interrogated using KEGG pathways. This yielded a complex network of 306 genes and again identified over-representation of ERB-B signaling. WNT signaling was also found to be significantly overrepresented in AH (Table 3). While SFRP1 can antagonize WNT signaling, it has been shown to also bind other proteins such as RANKL and thrombospondin, as well as affects signaling and responses via ER $\alpha$, TGF $\beta$, and p53 [30-32]. Furthermore, loss of SFRP1 is an early event observed in the MCF10A progression series [57]. Therefore, we tested whether loss of SFRP1 expression may regulate a portion of the genes within the $\mathrm{AH}$ signature. Inhibition of SFRP1 in immortalized normal breast epithelial cells mirrored the changes in expression of 13 genes that were differentially expressed in AH (Fig. 6b). Reexpression of SFRP1 in MCF7 cells reversed the changes in expression of 9 of the 13 genes tested (Fig. 6d). The presence of an SFRP-regulated gene network was also conserved in mouse mammary tissues (Fig. 6c). Consistent with these findings, the Sfrp1-/- mice exhibit precocious side-branching and hyperplasia of ductal/lobulo-alveolar units [35]. Together, these data demonstrate a role for SFRP1 in driving a portion of the signature found in $\mathrm{AH}$.

Several of the SFRP1-regulated genes are involved in signal transduction. Loss of SFRP1 expression had consistent effects resulting in increased expression of FOXA1, ERRB4, and KDM4B in both TERT-siSFRP1 cells and in mouse mammary tissues. FOXA1 is a pioneer factor which can open up chromatin to allow for access to $\mathrm{ER} \alpha$ transcriptional sites [58-60]. KDM4B is a histone demethylase which is upregulated in ER $\alpha+$ breast tumors and can regulate the expression of both ER $\alpha$ and FOXA1 as well as modulate ER $\alpha$ and p53 signaling [61-64], ERBB4/HER4 is critical for progesterone receptor (PR) expression [65] and has also been suggested to be responsible for promoting an autocrine proliferation pathway induced by estrogen $[66,67]$. The increased expression of FoxA1, Kdm4b, and Erbb4 a mammary glands of Sfrp1-/mice is consistent with the increased proportion of PR expressing cells and proliferation [32].
Analysis of ER $\alpha$ activity and endogenous ER $\alpha$ targets in our human cell lines also exhibited enhanced ERE reporter activity when SFRP1 was knocked down and repressed reporter activity when SFRP1 was re-expressed [32]. To confirm previous studies suggesting SFRP1 control of estrogen-induced PR expression, we added rSFRP1 to explants of normal breast tissue and demonstrated tempered induction of PR protein by estrogen (Fig. 7). Deletion of Sfrp1 in mice also resulted in enhanced estrogen-stimulated responses and occasional hyperplasias, but was not sufficient for the development of spontaneous mammary tumors [32, 35]. Therefore, loss of SFRP1 expression appears to be a key driver leading to broader alterations in gene expression and permitting increased signaling through ER $\alpha$ and derangements in the ERB-B and WNT pathways as well.

Although considered a "benign" lesion because progression to invasive cancer is relatively low, $\mathrm{AH}$ presage at least 40,000 breast cancer diagnoses annually [1, 68]. Therefore, intervention at this early stage offers the possibility of prevention of breast cancer. However, to minimize overtreatment, it is important to identify biomarkers discriminating the small subgroup of women with $\mathrm{AH}$ for whom risk is sufficiently high to warrant intervention. Molecular profiling of ductal carcinoma in situ aids in identifying women who may omit radiation following breast conserving surgery using a 12-gene panel (7 biomarkers, 5 reference genes) $[69,70]$. None of these 7 biomarkers were detected among the 1039 genes that were differentially expressed in $\mathrm{AH}$ compared to histologically normal epithelium (Additional file 2: Table S1). While the 99-gene signature discriminates $\mathrm{AH}$ tissues (Fig. 3), the study is not able to access the utility of the signature in assigning risk. Larger cohorts of pure $\mathrm{AH}$ with follow-up of $>20$ years for validation of predictive signatures are needed to identify women with $\mathrm{AH}$ who will benefit from interventions and reduce the potential for overtreatment [2].

\section{Conclusions}

These results identify differentially expressed genes that can be used to assist AH diagnoses. Loss of SFRP1 expression is a significant regulator of transcriptional profiles in $\mathrm{AH}$ and acts, in part, to limit estrogen signaling. These results support a broader role for SFRP1 in coordinating estrogen-induced responses and WNT signaling in normal breast epithelial cells.

\section{Additional files}

Additional file 1: Figure S1. The relative expression levels of SFRP1 mRNA are reduced in TERT-siSFRP1 cells and elevated in MCF7-SFRP1 cells. Total RNA was isolated from each cell line in triplicate for real-time PCR analysis. The level of SFRP1 mRNA was normalized to the amplification of 
ACTB mRNA, which was performed in parallel wells for each cell line. Bars represent mean \pm SEM SFRP1/ACTB and are expressed as relative expression of control cells (TERT-pSUPER or MCF7-pCDNA). ${ }^{* * *} p<0.001$ (significantly different from control cell lines using Student's $t$ test). (JPG $182 \mathrm{~kb}$ )

Additional file 2: Table S1. Probesets that are differentially expressed (1039 probesets). Table S2. Probesets selected by $p<0.005$ used for hierarchical clustering by AGNES (99 genes). Table S3. Probesets selected by PAM (139 genes). Table S4. Zero-order gene network. Table S5. Primers for RT-qPCR. (XLSX 204 kb)

\section{Abbreviations}

ADH: Atypical ductal hyperplasia; AH: Atypical hyperplasia; ALH: Atypical lobular hyperplasia; E2: 17ß-estradiol; ERa: Estrogen receptor alpha; FEA: Flat epithelial atypia; FFPE: Formalin-fixed paraffin-embedded; HNB: Histologically normal benign; IHC: Immunohistochemistry; LCIS: Lobular carcinoma in situ; PR: Progesterone receptor; RT-qPCR: Reverse transcriptase quantitative polymerase chain reaction

\section{Acknowledgements}

Not applicable.

\section{Authors' contributions}

$K J G, A L R$, and $B A B$ performed the laser capture microdissection and preparation of RNA for hybridization to microarrays. JAM and EMC performed the analysis of gene expression patterns. GMC and AK were responsible for selecting tissues. GMC provided histopathological diagnoses and marking $\mathrm{AH}$ lesions and HNB areas for microdissection. GM-J, GMC, and HSM assisted with acquiring tissues from women who were participants in the Rays of Hope Breast Research Registry. KS, JPSJ, JW, and JZ assisted with the network analyses. SSS, BS, and KJG contributed the analysis of gene expression in normal breast cell lines. DJJ, GMC, and KS were responsible for the design and overall conduct of the study. All authors read and approved the final manuscript.

\section{Authors' information}

Mailing address for DJ Jerry: 661 North Pleasant Street, Integrated Sciences Building, Room 427P, University of Massachusetts-Amherst, Amherst, MA 01003; Telephone: 413-794-0523.

http://pvlsi.org/d-joseph-jerry and https://www.vasci.umass.edu/researchfaculty/d-joseph-jerry

Mailing address for SS Schneider: 3601 Main Street, Pioneer Valley Life Sciences Institute, Springfield, MA 01199; Telephone: 413-794-0941 http:// pvlsi.org/sallie-smith-schneider

\section{Funding}

Research reported in this publication was supported, in part, by the Avon Foundation (DJJ), Rays of Hope Center for Breast Cancer Research (DJJ, GM-J), and National Institute of Environmental Health Sciences of the National Institutes of Health under award number U01ES026140 (DJJ, SSS). Additional support was provided by a Pilot Grant DJJ, KS) from the University of Massachusetts Medical Center Center for Clinical and Translational Sciences. The content is solely the responsibility of the authors and does not necessarily represent the official views of the National Institutes of Health.

\section{Availability of data and materials}

The gene expression microarray data have been deposited in the Gene Expression Omnibus repository. The series record is GSE118432.

\section{Ethics approval and consent to participate}

All samples are de-identified. Institutional Review Board approval was obtained from Baystate Health, Springfield, MA (protocol \# 182463).

\section{Consent for publication}

Not applicable.

\section{Competing interests}

The authors declare that they have no competing interests.

\section{Author details}

'Pioneer Valley Life Sciences Institute, Springfield, MA 01199, USA.

${ }^{2}$ Department of Veterinary and Animal Sciences, University of Massachusetts-Amherst, Amherst, MA 01003, USA. ${ }^{3}$ Department of Mathematics and Statistics, University of Massachusetts, Amherst, MA 01003, USA. ${ }^{4}$ Department of Pathology, University of Massachusetts Medical School/ Baystate, Springfield, MA 01199, USA. ${ }^{5}$ Division of Hematology-Oncology, University of Massachusetts Medical School/Baystate, Springfield, MA 01107 USA. 'Department of Surgery, University of Massachusetts Medical School/ Baystate, Springfield, MA 01199, USA. ${ }^{7}$ University of Massachusetts Medical School, Molecular, Cell, and Cancer Biology, Worcester, MA 01605, USA. ${ }^{8}$ Department of Pathology, University of Massachusetts Medical School, Worcester, MA 01605, USA. ${ }^{9}$ Division of Rheumatology, Immunology and Allergy, Brigham and Women's Hospital, Harvard Medical School, Boston, MA, USA.

Received: 7 December 2018 Accepted: 28 May 2019

Published online: 27 June 2019

\section{References}

1. Degnim AC, Visscher DW, Berman HK, Frost MH, Sellers TA, Vierkant RA, Maloney SD, Pankratz VS, de Groen PC, Lingle WL, et al. Stratification of breast cancer risk in women with atypia: a Mayo cohort study. J Clin Oncol. 2007;25(19):2671-7.

2. Kader T, Hill P, Rakha EA, Campbell IG, Gorringe KL. Atypical ductal hyperplasia: update on diagnosis, management, and molecular landscape. Breast Cancer Res. 2018;20(1):39.

3. Tice JA, O'Meara ES, Weaver DL, Vachon C, Ballard-Barbash R, Kerlikowske K. Benign breast disease, mammographic breast density, and the risk of breast cancer. J Natl Cancer Inst. 2013;105(14):1043-9.

4. Vogel VG, Costantino JP, Wickerham DL, Cronin WM, Cecchini RS, Atkins JN, Bevers TB, Fehrenbacher L, Pajon ER, Wade JL 3rd, et al. Update of the National Surgical Adjuvant Breast and Bowel Project Study of Tamoxifen and Raloxifene (STAR) P-2 Trial: preventing breast cancer. Cancer Prev Res. 2010;3(6):696-706

5. Goss PE, Ingle JN, Ales-Martinez JE, Cheung AM, Chlebowski RT, WactawskiWende J, McTiernan A, Robbins J, Johnson KC, Martin LW, et al. Exemestane for breast-cancer prevention in postmenopausal women. N Engl J Med. 2011;364(25):2381-91.

6. Cuzick J, Sestak I, Forbes JF, Dowsett M, Knox J, Cawthorn S, Saunders C, Roche N, Mansel RE, von Minckwitz G, et al. Anastrozole for prevention of breast cancer in high-risk postmenopausal women (IBISII): an international, double-blind, randomised placebo-controlled trial. Lancet. 2014;383(9922):1041-8.

7. Martinez AP, Cohen C, Hanley KZ, Li XB. Estrogen receptor and cytokeratin 5 are reliable markers to separate usual ductal hyperplasia from atypical ductal hyperplasia and low-grade ductal carcinoma in situ. Archives Pathol Laboratory Med. 2016;140(7):686-9.

8. Lee S, Mohsin SK, Mao S, Hilsenbeck SG, Medina D, Allred DC. Hormones, receptors, and growth in hyperplastic enlarged lobular units: early potential precursors of breast cancer. Breast Cancer Res. 2006;8(1):R6.

9. Barr FE, Degnim AC, Hartmann LC, Radisky DC, Boughey JC, Anderson SS, Vierkant RA, Frost MH, Visscher DW, Reynolds C. Estrogen receptor expression in atypical hyperplasia: lack of association with breast cancer. Cancer Prev Res. 2011;4(3):435-44.

10. Huh SJ, Oh H, Peterson MA, Almendro V, Hu R, Bowden M, Lis RL, Cotter MB, Loda M, Barry WT, et al. The proliferative activity of mammary epithelial cells in normal tissue predicts breast cancer risk in premenopausal women. Cancer Res. 2016;76(7):1926-34.

11. Radisky DC, Santisteban M, Berman HK, Gauthier ML, Frost MH, Reynolds CA, Vierkant RA, Pankratz VS, Visscher DW, TIsty TD, et al. p16(INK4a) expression and breast cancer risk in women with atypical hyperplasia. Cancer PrevRes (Phila). 2011;4(12):1953-60.

12. Ding L, Kleer CG. Enhancer of Zeste 2 as a marker of preneoplastic progression in the breast. Cancer Res. 2006;66(19):9352-5.

13. Park SY, Kwon HJ, Lee HE, Ryu HS, Kim SW, Kim JH, Kim IA, Jung N, Cho NY, Kang GH. Promoter CpG island hypermethylation during breast cancer progression. Virchows Archiv. 2011;458(1):73-84.

14. Dumont N, Crawford YG, Sigaroudinia M, Nagrani SS, Wilson MB, Buehring GC, Turashvili G, Aparicio S, Gauthier ML, Fordyce CA, et al. Human 
mammary cancer progression model recapitulates methylation events associated with breast premalignancy. Breast Cancer Res. 2009;11(6):R87.

15. van Hoesel $A Q$, Sato $Y$, Elashoff DA, Turner RR, Giuliano AE, Shamonki JM, Kuppen PJ, van de Velde CJ, Hoon DS. Assessment of DNA methylation status in early stages of breast cancer development. $\mathrm{Br} J$ Cancer. 2013;108(10):2033-8.

16. Hieken TJ, Carter JM, Hawse JR, Hoskin TL, Bois M, Frost M, Hartmann LC, Radisky DC, Visscher DW, Degnim AC. ERbeta expression and breast cancer risk prediction for women with atypias. Cancer Prev Res. 2015;8(11):1084-92.

17. Ma XJ, Salunga R, Tuggle JT, Gaudet J, Enright E, McQuary P, Payette T, Pistone M, Stecker K, Zhang BM, et al. Gene expression profiles of human breast cancer progression. Proc Natl Acad Sci USA. 2003;100(10):5974-9.

18. Poola I, DeWitty RL, Marshalleck JJ, Bhatnagar R, Abraham J, Leffall LD. Identification of MMP-1 as a putative breast cancer predictive marker by global gene expression analysis. Nat Med. 2005;11(5):481-3.

19. Gentleman RC, Carey VJ, Bates DM, Bolstad B, Dettling M, Dudoit S, Ellis B, Gautier L, Ge Y, Gentry J, et al. Bioconductor: open software development for computational biology and bioinformatics. Genome Biol. 2004;5(10):R80.

20. Piccolo SR, Sun Y, Campbell JD, Lenburg ME, Bild AH, Johnson WE. A singlesample microarray normalization method to facilitate personalized-medicine workflows. Genomics. 2012;100(6):337-44.

21. Piccolo SR, Withers MR, Francis OE, Bild AH, Johnson WE. Multiplatform single-sample estimates of transcriptional activation. Proc Natl Acad Sci U S A. 2013;110(44):17778-83.

22. Johnson WE, Li C, Rabinovic A. Adjusting batch effects in microarray expression data using empirical Bayes methods. Biostatistics. 2007;8(1):118-27.

23. Barrett T, Wilhite SE, Ledoux P, Evangelista C, Kim IF, Tomashevsky M, Marshall KA, Phillippy KH, Sherman PM, Holko M, et al. NCBI GEO: archive for functional genomics data sets--update. Nucleic Acids Res. 2013;41(Database issue):D991-5.

24. Smyth GK. Linear models and empirical bayes methods for assessing differential expression in microarray experiments. Stat Applications Genet Mol Biol. 2004;3:Article3.

25. Kaufman L, Rousseeuw PJ. Agglomerative Nesting (Program AGNES). In: Finding groups in data: an introduction to cluster analysis. Edn. Hoboken: Wiley; 2005. p. 199-249.

26. Kaufman L, Rousseeuw PJ. Partitioning around medoids (program PAM). In: Finding groups in data: an introduction to cluster analysis. Hoboken: Wiley; 2005. p. 68-122.

27. Xia J, Gill EE, Hancock RE. NetworkAnalyst for statistical, visual and network-based meta-analysis of gene expression data. Nat Protoc. 2015;10(6):823-44.

28. Shannon P, Markiel A, Ozier O, Baliga NS, Wang JT, Ramage D, Amin N, Schwikowski B, Ideker T. Cytoscape: a software environment for integrated models of biomolecular interaction networks. Genome Res. 2003;13(11):2498-504.

29. Cao Y, Gao Q, Wazer DE, Band V. Abrogation of wild-type p53-mediated transactivation is insufficient for mutant p53-induced immortalization of normal human mammary epithelial cells. Cancer Res. 1997:57(24):5584-9.

30. Gauger KJ, Chenausky KL, Murray ME, Schneider SS. SFRP1 reduction results in an increased sensitivity to TGF-beta signaling. BMC Cancer. 2011;11:59 59.

31. Gauger KJ, Hugh JM, Troester MA, Schneider SS. Down-regulation of sfrp1 in a mammary epithelial cell line promotes the development of a cd44high/ cd24low population which is invasive and resistant to anoikis. Cancer Cell Int. 2009;9:11 11 .

32. Gregory KJ, Schneider SS. Estrogen-mediated signaling is differentially affected by the expression levels of Sfrp1 in mammary epithelial cells. Cell Biol Int. 2015;39(7):873-9.

33. Chomczynski $P$, Sacchi N. Single-step method of RNA isolation by acid guanidinium thiocyanate-phenol-chloroform extraction. Anal Biochem. 1987;162(1):156-9.

34. Satoh W, Gotoh T, Tsunematsu Y, Aizawa S, Shimono A. Sfrp1 and Sfrp2 regulate anteroposterior axis elongation and somite segmentation during mouse embryogenesis. Development. 2006;133(6):989-99.

35. Gauger KJ, Shimono A, Crisi GM, Schneider SS. Loss of SFRP1 promotes ductal branching in the murine mammary gland. BMC Dev Biol. 2012;12:25. https://doi.org/10.1186/1471-213X-12-25.:25-12.

36. Dabbs DJ, Schnitt SJ, Geyer FC, Weigelt B, Baehner FL, Decker T, Eusebi V, Fox SB, Ichihara S, Lakhani SR, et al. Lobular neoplasia of the breast revisited with emphasis on the role of E-cadherin immunohistochemistry. Am J Surg Pathol. 2013;37(7):e1-11.
37. Brunner AL, Li J, Guo X, Sweeney RT, Varma S, Zhu SX, Li R, Tibshirani R, West RB. A shared transcriptional program in early breast neoplasias despite genetic and clinical distinctions. Genome Biol. 2014;15(5):R71.

38. Aran D, Camarda R, Odegaard J, Paik H, Oskotsky B, Krings G, Goga A, Sirota M, Butte AJ. Comprehensive analysis of normal adjacent to tumor transcriptomes. Nat Commun. 2017;8(1):1077.

39. Graham K, Ge X, de las MA, Tripathi A, Rosenberg CL. Gene expression profiles of estrogen receptor-positive and estrogen receptor-negative breast cancers are detectable in histologically normal breast epithelium. Clin Cancer Res. 2011.

40. Deng G, Lu Y, Zlotnikov G, Thor AD, Smith HS. Loss of heterozygosity in normal tissue adjacent to breast carcinomas. Science. 1996;274:2057-9.

41. Troester MA, Hoadley KA, D'Arcy M, Cherniack AD, Stewart C, Koboldt DC, Robertson AG, Mahurkar S, Shen H, Wilkerson MD, et al. DNA defects, epigenetics, and gene expression in cancer-adjacent breast: a study from The Cancer Genome Atlas. NPJ Breast Cancer. 2016;2:16007.

42. Elmore JG, Longton GM, Carney PA, Geller BM, Onega T, Tosteson AN, Nelson HD, Pepe MS, Allison KH, Schnitt SJ, et al. Diagnostic concordance among pathologists interpreting breast biopsy specimens. JAMA. 2015;313(11):1122-32.

43. Jain RK, Mehta R, Dimitrov R, Larsson LG, Musto PM, Hodges KB, Ulbright TM, Hattab EM, Agaram N, Idrees MT, et al. Atypical ductal hyperplasia: interobserver and intraobserver variability. ModPathol. 2011;24(7):917-23.

44. Lammie A, Drobnjak M, Gerald W, Saad A, Cote R, Cordon-Cardo C. Expression of c-kit and kit ligand proteins in normal human tissues. J Histochem Cytochemistry. 1994;42(11):1417-25.

45. Crisi GM, Marconi SA, Makari-Judson G, Goulart RA. Expression of c-kit in adenoid cystic carcinoma of the breast. Am J Clin Pathol. 2005;124(5):733-9.

46. Piggin CL, Roden DL, Gallego-Ortega D, Lee HJ, Oakes SR, Ormandy CJ. ELF5 isoform expression is tissue-specific and significantly altered in cancer. Breast Cancer Res. 2016;18(1):4.

47. Lee S, Medina D, Tsimelzon A, Mohsin SK, Mao S, Wu Y, Allred DC. Alterations of gene expression in the development of early hyperplastic precursors of breast cancer. Am J Pathol. 2007;171(1):252-62.

48. Sun H, Miao Z, Zhang X, Chan UI, Su SM, Guo S, Wong CKH, Xu X, Deng CX. Single-cell RNA-Seq reveals cell heterogeneity and hierarchy within mouse mammary epithelia. J Biol Chem. 2018;293(22):8315-29.

49. Pal B, Chen Y, Vaillant F, Jamieson P, Gordon L, Rios AC, Wilcox S, Fu N, Liu $\mathrm{KH}$, Jackling $\mathrm{FC}$, et al. Construction of developmental lineage relationships in the mouse mammary gland by single-cell RNA profiling. Nat Commun. 2017;8(1):1627.

50. Nguyen QH, Pervolarakis N, Blake K, Ma D, Davis RT, James N, Phung AT, Willey E, Kumar R, Jabart E, et al. Profiling human breast epithelial cells using single cell RNA sequencing identifies cell diversity. Nat Commun. 2018;9(1):2028.

51. Bombonati A, Sgroi DC. The molecular pathology of breast cancer progression. J Pathol. 2011;223(2):307-17.

52. Bertucci F, Orsetti B, Negre V, Finetti P, Rouge C, Ahomadegbe JC, Bibeau F, Mathieu MC, Treilleux I, Jacquemier J, et al. Lobular and ductal carcinomas of the breast have distinct genomic and expression profiles. Oncogene. 2008;27(40):5359-72.

53. Weigelt B, Geyer FC, Natrajan R, Lopez-Garcia MA, Ahmad AS, Savage K, Kreike B, Reis-Filho JS. The molecular underpinning of lobular histological growth pattern: a genome-wide transcriptomic analysis of invasive lobular carcinomas and grade- and molecular subtype-matched invasive ductal carcinomas of no special type. J Pathol. 2010;220(1):45-57.

54. Ciriello G, Gatza ML, Beck AH, Wilkerson MD, Rhie SK, Pastore A, Zhang H, McLellan M, Yau C, Kandoth C, et al. Comprehensive molecular portraits of invasive lobular breast cancer. Cell. 2015;163(2):506-19.

55. Fisher B, Costantino JP, Wickerham DL, Redmond CK, Kavanah M, Cronin WM, Vogel V, Robidoux A, Dimitrov N, Atkins J, et al. Tamoxifen for prevention of breast cancer: report of the National Surgical Adjuvant Breast and Bowel Project P-1 Study. J Natl Cancer Inst. 1998;90(18):1371-88.

56. Coopey SB, Mazzola E, Buckley JM, Sharko J, Belli AK, Kim EM, Polubriaginof F, Parmigiani G, Garber JE, Smith BL, et al. The role of chemoprevention in modifying the risk of breast cancer in women with atypical breast lesions. Breast Cancer Res Treat. 2012;136(3):627-33.

57. Kothari C, Ouellette G, Labrie Y, Jacob S, Diorio C, Durocher F. Identification of a gene signature for different stages of breast cancer development that could be used for early diagnosis and specific therapy. Oncotarget. 2018;9(100):37407-20. 
58. Chen F, Li A, Gao S, Hollern D, Williams M, Liu F, VanSickle EA, Andrechek E, Zhang C, Yang C, et al. Tip30 controls differentiation of murine mammary luminal progenitor to estrogen receptor-positive luminal cell through regulating FoxA1 expression. Cell Death Dis. 2014:5:e1242.

59. Watters RJ, Benos PV, Oesterreich S. To bind or not to bind--FoxA1 determines estrogen receptor action in breast cancer progression. Breast Cancer Res. 2012;14(3):312.

60. Hurtado A, Holmes KA, Ross-Innes CS, Schmidt D, Carroll JS. FOXA1 is a key determinant of estrogen receptor function and endocrine response. Nat Genet. 2011;43(1):27-33.

61. Castellini L, Moon EJ, Razorenova OV, Krieg AJ, von Eyben R, Giaccia AJ. $\mathrm{KDM} 4 \mathrm{~B} / \mathrm{JMJD2B}$ is a p53 target gene that modulates the amplitude of p53 response after DNA damage. Nucleic Acids Res. 2017;45(7):3674-92.

62. Kawazu M, Saso K, Tong Kl, McQuire T, Goto K, Son DO, Wakeham A, Miyagishi M, Mak TW, Okada H. Histone demethylase JMJD2B functions as a co-factor of estrogen receptor in breast cancer proliferation and mammary gland development. PLoS One. 2011;6(3):e17830.

63. Young LC, McDonald DW, Hendzel MJ. Kdm4b histone demethylase is a DNA damage response protein and confers a survival advantage following gamma-irradiation. J Biol Chem. 2013;288(29):21376-88.

64. Yang J, Jubb AM, Pike L, Buffa FM, Turley H, Baban D, Leek R, Gatter KC, Ragoussis J, Harris AL. The histone demethylase JMJD2B is regulated by estrogen receptor alpha and hypoxia, and is a key mediator of estrogen induced growth. Cancer Res. 2010;70(16):6456-66.

65. Rokicki J, Das PM, Giltnane JM, Wansbury O, Rimm DL, Howard BA, Jones FE. The ERalpha coactivator, HER4/4ICD, regulates progesterone receptor expression in normal and malignant breast epithelium. Mol Cancer. 2010;9:150.

66. Han W, Jones FE. HER4 selectively coregulates estrogen stimulated genes associated with breast tumor cell proliferation. Biochem Biophys Res Commun. 2014;443(2):458-63.

67. Zhu Y, Sullivan LL, Nair SS, Williams CC, Pandey AK, Marrero L, Vadlamudi RK, Jones FE. Coregulation of estrogen receptor by ERBB4/HER4 establishes a growth-promoting autocrine signal in breast tumor cells. Cancer Res. 2006;66(16):7991-8.

68. Collins LC, Baer HJ, Tamimi RM, Connolly JL, Colditz GA, Schnitt SJ. Magnitude and laterality of breast cancer risk according to histologic type of atypical hyperplasia: results from the Nurses' Health Study. Cancer. 2007:109(2):180-7.

69. Rakovitch E, Nofech-Mozes S, Hanna W, Baehner FL, Saskin R, Butler SM, Tuck A, Sengupta S, Elavathil L, Jani PA, et al. A population-based validation study of the DCIS Score predicting recurrence risk in individuals treated by breast-conserving surgery alone. Breast Cancer Res Treat. 2015;152(2):389-98.

70. Solin L, Gray R, Baehner FL, Butler SM, Hughes LL, Yoshizawa C, Cherbavaz DB, Shak S, Page DL, Sledge GW Jr, et al. A multigene expression assay to predict local recurrence risk for ductal carcinoma in situ of the breast. J Natl Cancer Inst. 2013;105(10):701-10.

\section{Publisher's Note}

Springer Nature remains neutral with regard to jurisdictional claims in published maps and institutional affiliations.

Ready to submit your research? Choose BMC and benefit from:
- fast, convenient online submission
- thorough peer review by experienced researchers in your field
- rapid publication on acceptance
- support for research data, including large and complex data types
- gold Open Access which fosters wider collaboration and increased citations
- maximum visibility for your research: over 100M website views per year
At BMC, research is always in progress.
Learn more biomedcentral.com/submissions

